\title{
Pan-Arctic seasonal cycles and long-term trends of aerosol properties from ten observatories
}

Julia Schmale ${ }^{1}$, Sangeeta Sharma ${ }^{2}$, Stefano Decesari ${ }^{3}$, Jakob Pernov ${ }^{4}$, Andreas Massling ${ }^{4}$, Hans-Christen Hansson $^{5}$, Knut von Salzen ${ }^{2}$, Henrik Skov ${ }^{4}$, Elisabeth Andrews', Patricia K. Quinn ${ }^{7}$, Lucia M. Upchurch $^{7,8}$, Konstantinos Eleftheriadis ${ }^{9}$, Rita Traversi ${ }^{10,11}$

${ }^{1}$ Extreme Environments Research Laboratory, École Polytechnique fédérale de Lausanne, 1951 Sion, Switzerland

${ }^{2}$ Environment and Climate Change Canada, Science and Technology Branch, Climate Research Division,

104905 Dufferin Street, Toronto, Ontario M5T 3H4, Canada

${ }^{3}$ Institute of Atmospheric Sciences and Climate, National Research Council of Italy, 40129 Bologna, Italy

${ }^{4}$ Department of Environmental Science, iClimate, Aarhus University, Frederiksborgvej 399, 4000 Roskilde, Denmark

${ }^{5}$ Department of Environmental Science, Stockholm University, 10691 Stockholm, Sweden

$15{ }^{6}$ Cooperative Institute for Research in Environmental Sciences (CIRES), University of Colorado, Boulder, Colorado 80309, USA

${ }^{7}$ Pacific Marine Environmental Laboratory, National Oceanic and Atmospheric Administration, Seattle, WA, USA

${ }^{8}$ Cooperative Institute for Climate, Ocean, and Ecosystem Studies, University of Washington, Seattle,

20 WA, USA

${ }^{9}$ NCSR "Demokritos"-Institute of Nuclear and Radiological Sciences and Technology, Energy and Safety Environmental Radioactivity Laboratory, 15310 Athens, Greece

${ }^{10}$ Department of Chemistry "Ugo Schiff”, University of Florence, 50019 Sesto F.no (Florence), Italy.

${ }^{11}$ Institute of Polar Sciences, ISP-CNR, University of Venice, 30172 Venice, Italy

Julia Schmale ORCID 0000-0002-1048-7962

Stefano Decesari ORCID 0000-0001-6486-3786

Jakob Boyd Pernov ORCID 0000-0003-1906-2589

Rita Traversi ORCID 0000-0002-9790-2195

Patricia K. Quinn ORCID 0000-0003-0337-4895

Lucia M. Upchurch ORCID 0000-0003-1351-6332

Elisabeth Andrews ORCID 0000-0002-9394-024X

Kostas Eleftheriadis ORCID 0000-0003-2265-4905

Andreas Massling ORCID 0000-0001-8046-2798

Henrik Skov ORCID 0000-0003-1167-8696

Sangeeta Sharma ORCID 0000-0002-9071-1812

Knut von Salzen ORCID 0000-0002-2991-6181

Hans-Christen Hansson ORCID 0000-0001-7794-2889

Correspondence to: Julia Schmale (julia.schmale @epfl.ch) 


\section{Abstract.}

Even though the Arctic is remote, aerosol properties observed there are strongly influenced by anthropogenic emissions from outside the Arctic. This is particularly true for the so-called Arctic haze season (January through April). In summer (June through September), when atmospheric transport patterns change, and precipitation is more frequent, local Arctic, i.e. natural sources of aerosols and precursors, play an important role. Over the last decades, significant reductions in anthropogenic emissions have taken place. At the same time a large body of literature shows evidence that the Arctic is undergoing fundamental environmental changes due to climate forcing, leading to enhanced emissions by natural processes that may impact aerosol properties.

In this study, we analyze nine aerosol chemical species and four particle optical properties from ten Arctic observatories (Alert, Gruvebadet, Kevo, Pallas, Summit, Thule, Tiksi, Barrow, Villum, Zeppelin) to understand changes in anthropogenic and natural aerosol contributions. Variables include equivalent black carbon, particulate sulfate, nitrate, ammonium, methanesulfonic acid, sodium, iron, calcium and potassium, as well as scattering and absorption coefficients, single scattering albedo and scattering Ångström exponent.

First, annual cycles are investigated, which despite anthropogenic emission reductions still show the Arctic haze phenomenon. Second, long-term trends are studied using the Mann-Kendall Theil-Sen slope method. We find in total 28 significant trends over full station records, i.e. spanning more than a decade, compared to 17 significant decadal trends. The majority of significantly declining trends is from anthropogenic tracers and occurred during the haze period, driven by emission changes between 1990 and 2000. For the summer period, no uniform picture of trends has emerged. Twenty-one percent of trends, i.e. eleven out of 57, are significant, and of those five are positive and six are negative. Negative trends include not only anthropogenic tracers such as equivalent black carbon at Kevo, but also natural indicators such as methanesulfonic acid and non-sea salt calcium at Alert. Positive trends are observed for sulfate at Zeppelin and Gruvebadet.

No clear evidence of a significant change in the natural aerosol contribution can be observed yet. However, testing the sensitivity of the Mann-Kendall Theil-Sen method, we find that monotonic

70 changes of around $5 \%$ per year in an aerosol property are needed to detect a significant trend within one decade. This highlights that long-term efforts well beyond a decade are needed to capture smaller changes. It is particularly important to understand the ongoing natural changes in the Arctic, where interannual variability can be high, such as with forest fire emissions and their influence on the aerosol population.

75 To investigate the climate-change induced influence on the aerosol population and the resulting climate feedback, long-term observations of tracers more specific to natural sources are needed, as well as of particle microphysical properties such as size distributions, which can be used to identify changes in particle populations which are not well captured by mass-oriented methods such as bulk chemical composition. 


\section{Introduction}

Despite its remoteness, the Arctic is a main receptor of anthropogenic air pollutant emissions from the Arctic equilibrium temperature response is in total $+0.35^{\circ} \mathrm{C}$ due to forcing from black carbon $(\mathrm{BC})$ in the atmosphere $\left(+0.40{ }^{\circ} \mathrm{C}\right)$, BC on snow $\left(+0.22{ }^{\circ} \mathrm{C}\right)$, atmospheric organic carbon $\left(-0.04{ }^{\circ} \mathrm{C}\right)$ and particulate sulfate $\left(-0.23{ }^{\circ} \mathrm{C}\right)$.

Surface monitoring sites around the Arctic (Fig. 1) have been operated to determine air pollutants at Barrow, USA (Bodhaine and Dutton, 1993), the 1980s at Alert, Canada (Sturges and Barrie, 1989), the 1990s at Zeppelin, Svalbard (Platt et al., 2021) and Villum Research Station, Greenland (Nguyen et al., 2016; Heidam et al., 1999), and more recently at a number of other observatories such as Summit, Greenland (Schmeisser et al., 2018), Tiksi, Russia (Asmi et al., 2016), Gruvebadet, Svalbard (Gilardoni, 2019; Traversi et al., 2021), Thule, Greenland (Becagli et al., 2019) and at Pallas, Finland (Aaltonen et al., 2006). Observations at these stations cover a wide range of aerosol properties including their chemical composition, i.e. particulate sulfate $\left(\mathrm{SO}_{4}^{-2}\right)$, nitrate $\left(\mathrm{NO}_{3}{ }^{-}\right)$, ammonium $\left(\mathrm{NH}_{4}{ }^{+}\right)$, mainly based on filter collection and subsequent laboratory analysis, and optical properties such as scattering and absorption coefficients and derived equivalent black carbon (EBC) concentrations. Using the Eclipse V4.0a emission inventory and state of the art models, AMAP et al. (2015) found that emission sources in East and South Asia and Russia are the largest contributors to black carbon burden in the Arctic, with particularly large contributions of domestic sources in East and South Asia, and emissions from wildfires and gas flaring in Russia. Depending on the location of the observations, different source regions become relevant (Backman et al., 2021). Based on Lagrangian transport model simulations, Hirdman et al. (2010b) showed 
110 for Zeppelin, Barrow and Alert that northern Eurasia is the main source region, whereas emissions from North America are less influential. The Summit observatory located above $3000 \mathrm{~m}$ a.s.l. is more susceptible to emissions of Southern Europe (Hirdman et al., 2010b), since those are uplifted and arrive at the Arctic further aloft. From a near sea level surface observatory perspective, emissions in Asia and particularly southern Asia are less important because they are transported through the higher troposphere and do not significantly influence boundary layer measurements (AMAP, 2015; Shindell et al., 2008). Seasonality of BC can be very different depending on the altitude. Mahmood et al. (2016) showed that, for example, $\mathrm{BC}$ in the upper troposphere is only weakly influenced by wet deposition in stratiform clouds, whereas lower tropospheric Arctic BC concentrations are highly sensitive to wet deposition.

The surface site observations have created a large data resource (for a history on monitoring sites see,

120 Platt et al., 2021), which has been analyzed for seasonal cycles. The seasonal cycle of aerosols in the Arctic is generally driven by atmospheric transport patterns, which, during winter and early spring, favor long-range transport from mid-latitudes and removal processes are minimal allowing for long aerosol lifetimes and accumulation of pollutants (e.g., Stohl, 2006). This leads to the build-up of air pollution, the so-called Arctic haze (Heidam, 1981; Barrie, 1986; Schnell, 1984; Radke et al., 1976). During summer, the Arctic front is located far to the north and the Arctic dome largely prevents transport of particles from sources at mid-latitude from reaching the high Arctic. The summertime Arctic atmosphere is much less stratified and frequent precipitation removes aerosols efficiently, while simultaneously, conditions for long-range transport of pollution are also less frequent. Hence, the summer boundary layer is characterized by much lower aerosol concentrations, predominantly reflecting local and regional emissions. Overall, the seasonality of aerosol properties at Arctic sites depends on the geographical sectors, and on how the specific sites are connected to upstream pollution sources through atmospheric transport. Sharma et al. (2019) analyzed annual cycles of 20 aerosol constituents at Alert. In brief, for all anthropogenic tracers they find a winter peak and a summer minimum, as expected. For some natural tracers, such as iodine, methanesulfonic acid (MSA) and mineral dust, they find two modes, one in spring

135 and the other in summer/fall. For mineral dust the spring peak represents long-range transported dust, while the summer/fall peak reflects more local emissions when the snow cover is at a minimum. Similarly, for MSA, an oxidation product from dimethyl sulfide (DMS), which is derived from marine microbial 
activity, the spring maximum reflects long-range transport, while the summer maximum is due to more local emissions. The reasons for the iodine pattern are not entirely clear but they are related likely to the return of the sun in spring and freeze-up processes in fall (Baccarini et al., 2020). For other natural tracers, such as sodium $\left(\mathrm{Na}^{+}\right)$and chloride $\left(\mathrm{Cl}^{-}\right)$, which mainly originate from sea salt, they find a winter maximum, which is driven by sublimating blowing snow leaving behind salt particles (Huang and Jaeglé, 2017; Fenger et al., 2013). Quinn et al. (2007) reported annual cycles of anthropogenic haze tracers for Barrow, Alert, Villum, Zeppelin and several other Eurasian stations. Eckhardt et al. (2015) compiled annual $\mathrm{BC}$ and $\mathrm{SO}_{4}{ }^{2-}$ data from the same four stations, as well as Tiksi and Pallas in addition for a model evaluation. Backman et al. (2017) systematically evaluated aethalometer measurements of black carbon from Barrow, Alert, Zeppelin, Summit, Pallas and Tiski, and Schmeisser et al. (2018) used the same data for a systematic analysis of seasonal cycles of aerosol optical parameters. While the seasonal patterns of the aerosol scattering and absorption coefficients follow the pattern of anthropogenic tracers in the Arctic for four of the sites, Summit and Pallas show unique signals, where the maximum is in summer rather than winter. They attribute this difference to the higher load of natural aerosol emissions from the boreal forest around Pallas (Tunved et al., 2006, 2003) and the long-range transport of fire emissions to Summit during summer (Stohl et al., 2006).

The same or extended database used for the study of annual cycles has been used in a number of studies

155 for long-term trend analyses. The longest time series of black carbon measurements was collected at Kevo, Finland, where annual concentrations decreased by 73\% between about 1970 and 2010 (Dutkiewicz et al., 2014). Sharma et al. (2006) and Quinn et al. (2007) found a $33 \%$ decline between 1989 and 2003 for Barrow during the haze season. The analysis was updated by Sharma et al. (2013), who found a roughly $40 \%$ decrease for Barrow, Alert and Zeppelin between 1990 and 2009. More recent work by Sharma et al. $(2017,2019)$ extended the analysis until 2013 , reporting a roughly $50 \%$ decrease of black carbon since 1990 during the haze season. The authors ascribe the decline firstly to the economic changes in the former Soviet Union and secondly to air quality policies in Europe. Observations for $\mathrm{SO}_{4}{ }^{2-}$ are analogous for Alert, also with a $50 \%$ decline over the same time period (Sharma et al., 2019). Hirdman et al. (2010a) derived trends based on annual geometric mean data and found a $21.5 \%$ decline at Zeppelin 
165 between 1990 and 2008 in non-sea salt sulfate $\left(\mathrm{nsSOO}_{4}{ }^{2-}\right)$ and no trend for Barrow between 1997 and 2006. The absence of a trend at the latter station is potentially because of the short time period investigated. The results for Zeppelin are somewhat in contrast to Platt et al. (2021) who find a decline of $44 \%$ between 1990 and 2019. EBC and nssSO$_{4}{ }^{-2}$ are typical anthropogenic combustion tracers during the haze season, and therefore show significant negative trends at several stations during winter in the past

170 decades (Dutkiewicz et al., 2014; Sharma et al., 2019). For summer, a much smaller number of significantly decreasing concentrations has been reported. This is partly because during summer, anthropogenic emissions are transported much less effectively to the Arctic, and EBC as well as $\mathrm{nssSO}_{4}{ }^{2-}$ can also be emitted or derived from natural sources such as wildfires and marine organisms, respectively. The Arctic is undergoing rapid and unprecedented socio-economic as well as environmental changes. The region is warming two to three times faster than the global average, a phenomenon called Arctic amplification (Serreze and Barry, 2011). Sea ice has declined by more than $30 \%$ since the 1970s (Meier et al., 2014), marine microbial activity is changing significantly (Arrigo et al., 2012) and up to 50\% increase in wild fire occurrence in the circumboreal region is expected by the end of the century (Flannigan et al., 2009). These changes may have important implications for natural aerosol emissions 180 and abundance (Schmale et al., 2021), particularly in summer, when e.g., BC and OC are emitted from wild fires. Despite the increase in fire emissions in higher latitudes in the past years, no increased contribution during the fire season has been shown so far. This is likely due to the fact that wild fires emit $\mathrm{BC}$ and $\mathrm{OC}$ further aloft into the atmosphere and in the absence of down-mixing to the boundary layer such aerosol layers are mostly not captured by surface observations. From carbon source apportionment 185 studies based on isotopic ratios, it is known that biomass burning dominates the summertime EBC signal (Winiger et al., 2019). However, there are no long-term isotopic observations, and thus, it is unknown whether the summertime dominance is a new phenomenon or not. In terms of socio-economic changes, impact of emissions from oil fields (e.g., Prudhoe Bay in Alaska), shipping (e.g., in Resolute Bay, Canada), flaring (e.g., in Siberia) and Arctic urban areas have been found to change aerosol composition 190 as well as cloud properties (Kolesar et al., 2017; Aliabadi et al., 2015; Schmale et al., 2018; Gunsch et al., 2017). 
$\mathrm{NssSO}_{4}{ }^{2-}$ can originate from the oxidation of DMS to $\mathrm{SO}_{2}$ and further to sulfuric acid (Hoffmann et al., 2016), which can then condense onto preexisting particles and contribute to cloud condensation nuclei or form new ones (Hodshire et al., 2019; Beck et al., 2020; Schmale and Baccarini, 2021; Park et al., 2021). DMS is also converted into MSA in the atmosphere (Hoffmann et al., 2016). It is hypothesized that retreating sea ice allows for more algal blooms in the Arctic Ocean, which would result in more DMS emissions and hence more particulate MSA, a unique tracer for this change. Gali et al. (2019) showed a significant increase in DMS emissions between 1998 and 2016 north of $70^{\circ} \mathrm{N}$. A few studies have investigated the trends of particulate MSA and $\mathrm{nsSSO}_{4}{ }^{-2}$ in the Arctic. Recently, Moffett et al. (2020) found for Barrow that MSA and nssSO ${ }_{4}^{-2}$ increased by $2.5 \%$ and $2.1 \%$ per year (July to September), respectively, in the period 1998 to 2017. The authors find a positive correlation with ambient temperature and hypothesize that the trend might result from a mixture of causes, which include retreating sea ice, warmer sea surface temperature and temperature dependent atmospheric chemical reactions. At Alert, Sharma et al. (2019) found no significant trend in MSA between 1998 and 2013, while there was a $4 \%$ increase per year (July to August) between 1998 and 2008 (Sharma et al., 2012), reflecting natural variability rather than the effect of sea ice retreat. A study of MSA concentrations at Gruvebadet, Svalbard, and Thule, Greenland between 2010 and 2017 showed that the relationship between retreating sea ice and particulate MSA is complex and likely not direct (Becagli et al., 2019). While concentrations seem to have a positive trend at Gruvebadet, they tend to decline at Thule, while sea ice is retreating in both locations. The presence of algae responsible for the production of DMS precursors in the water is necessary for DMS release to the atmosphere and subsequent production of MSA. A modelling study has shown that even if more DMS is emitted, it does not mean that higher particulate MSA is observed at the surface stations, because MSA might be incorporated into cloud condensation nuclei $(\mathrm{CCN})$ which are preferentially removed from the atmosphere through wet deposition further amplified by the fact that there is an increase in precipitating clouds with retreating sea ice (Mahmood et al., 2019).

Another important natural aerosol component around the Arctic is sea spray, composed of sea salt and organics. Modeling studies have investigated the climatic effects following the hypothesis that retreating sea ice will lead to more sea spray production (Browse et al., 2014; Struthers et al., 2011). However, 
long-term observations that show an increased contribution of sea spray are scarce. Increasing trends in sea salt produced by the sea spray were identified at Alert in 34 years of measurements of $\mathrm{Na}^{+}$and $\mathrm{Cl}^{-}$ (Sharma et al., 2019). Recently, Heslin-Rees et al. (2020) have analyzed long-term trends of aerosol optical properties from Zeppelin, Svalbard. They found that the scattering Ångström exponent ( $S A E$ ) became significantly smaller over time. A smaller SAE indicates in general larger particle diameters, and hence the results provide evidence for a change in particle diameters towards larger sizes. Given that coarse mode particle sources in the Arctic are limited, long-range transported mineral dust or local soil dust are other potential sources, but sea spray is the main contributing factor. The authors find, however, that the increased coarse mode is a result of changing atmospheric air mass advection patterns rather than enhancement of sea spray production in regions with retreated sea ice. In winter, $\mathrm{Na}^{+}$is dominated by blowing snow signals. Higher sea salt contributions at Alert from January to March (Sharma et al., 2019) are found to be due to wind driven resuspension of sea salt originally deposited on the snowpack from long range transport of sea salt from the North Atlantic Ocean. This contribution is more important than that from frost flowers (Huang and Jaeglé, 2017) as supported by sulfur isotope analysis (Seguin et al., 2014). Kirpes et al. (2018) investigated particulate $\mathrm{Na}^{+}$at Barrow in winter and found that sea spray emissions most likely from open leads or open water were responsible for a considerable fraction of sea salt, rather than blowing snow. This might be an indication for a shift in sea salt sources during winter. However, no long-term analyses have been done.

Summarizing the large body of literature treating annual cycles and long-term trends at Arctic observatories, we find three main approaches: (i) studies investigated a limited number of aerosol properties across multiple stations for a short period of time (e.g. the systematic comparison of optical 240 properties (Schmeisser et al., 2018) or BC and $\mathrm{SO}_{4}{ }^{2-}$ (Eckhardt et al., 2015), (ii) studies focused on one station entirely reporting a large number of parameters for seasonal cycle and trend analyses (e.g., Sharma et al., 2019), or (iii) studies discussed long-term trends of a small number of anthropogenic tracers across multiple stations over different time periods (e.g., Quinn et al., 2007; Collaud Coen et al., 2020b). The resulting gaps are a missing pan-Arctic synthesis of anthropogenic and natural seasonal and long-term 245 trend patterns over comparable time-periods, as well as a joint consideration of chemical and optical aerosol properties and their seasonal and long-term co-evolution. 
To close these gaps, here, we discuss seasonal cycles of nine chemical and four optical properties across ten stations averaged over the same time-period, and we derive decadal trends per variable and station, which can be compared to each other. We further include anthropogenic as well as natural aerosol tracers. 250 The purpose of this study is twofold: (i) we aim to reveal similarities and differences in seasonal patterns to highlight the regional nature of the Arctic aerosol regimes, and (ii) to contrast anthropogenic and natural aerosol long-term trends against decreasing anthropogenic emissions and discuss these trends in the context of environmental changes. This study follows chapter 5 of the recently released assessment report of short-lived climate forcers in the Arctic by the Arctic Monitoring and Assessment Programme (AMAP, 255 2021). 


\section{Methods}

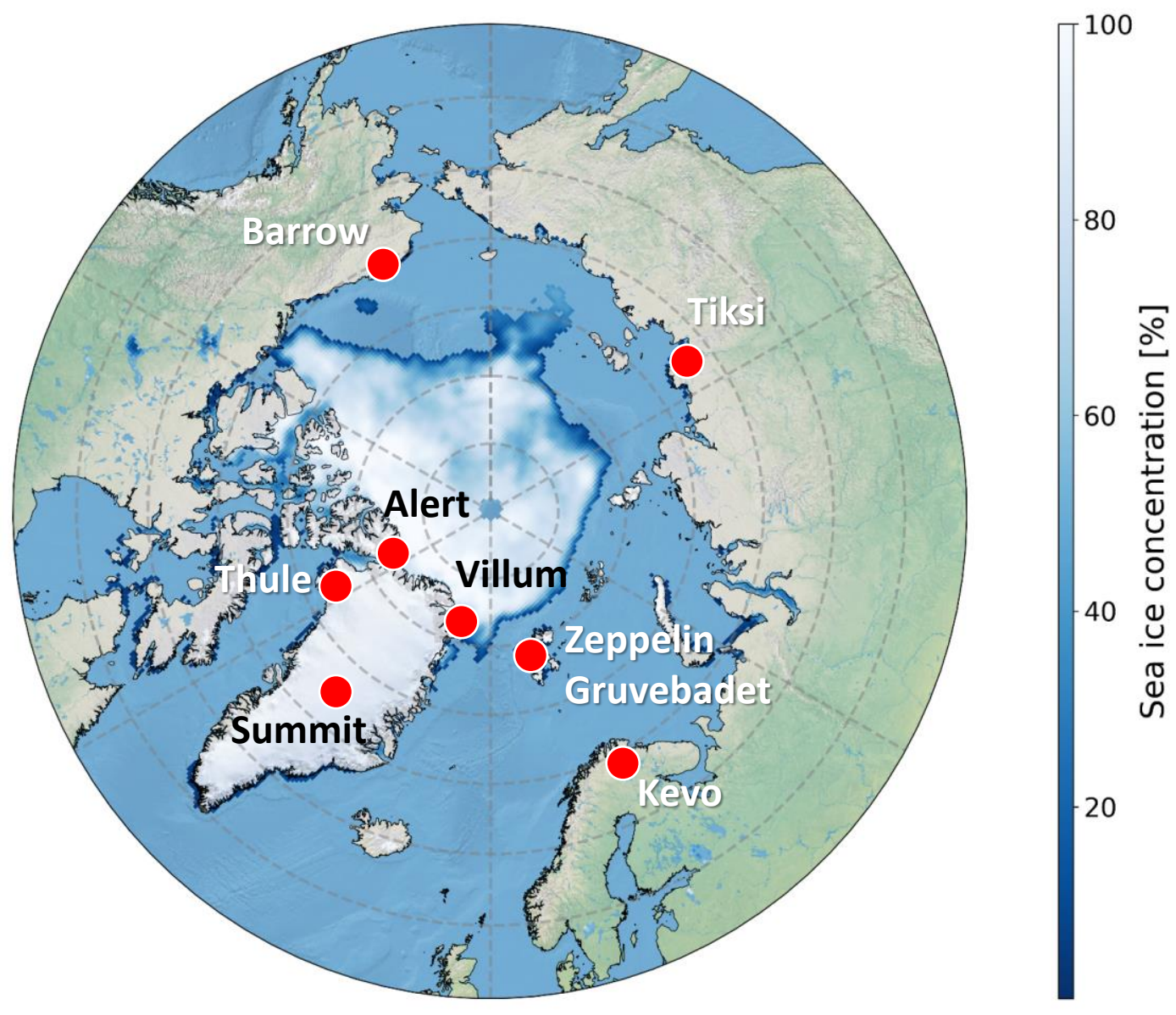

260 Figure 1: Location of observatories discussed in this study. The blue shading represents sea ice concentration (15 September 2018), reported as a fraction of covered surface (Maslanik and Stroeve, 1999). The base map is from Natural Earth II (https://www.naturalearthdata.com/).

\subsection{Data and data treatment}

We obtained final, corrected data either from a publicly accessible data repository (EBAS, $\underline{\text { http://ebas.nilu.no/) }}$ or through personal communication with station PIs (see Table 1). Data temporal resolution varied from hourly for aerosol optical properties to several days for chemical components. Figure 1 shows data from ten observatories where various in situ measurements were conducted. The 
chemical variables we consider include equivalent black carbon $(\mathrm{EBC})$, particulate sulfate $\left(\mathrm{SO}_{4}{ }^{2-}\right)$, nitrate $\left(\right.$ nssK ${ }^{+}$) and iron $(\mathrm{Fe})$. We calculated the nss components $\mathrm{Ca}^{2+}$ and $\mathrm{K}^{+}$based on their abundance in sea salt relative to the $\mathrm{Na}^{+}$concentration (Pilson, 2012). The former can be regarded as tracer for soil dust and the latter for biomass burning (e.g., Sharma et al., 2019). Table 1 gives an overview of the measurement methodology for each species at the different sampling sites.

275 We also report four different optical properties, the scattering $\left(\sigma_{s p}\right)$ and absorption $\left(\sigma_{a p}\right)$ coefficients at $550 \mathrm{~nm}$, single scattering albedo $(S S A)$ at $550 \mathrm{~nm}$, and scattering Ångström exponent at 550/450 (SAE). While the first two variables depend on the total aerosol concentration, i.e. extensive properties, the SSA and $S A E$ are intensive properties which do not depend on loading. The $S S A$ is a measure of how much the aerosol population is able to scatter light relative to the extinction (absorption+scattering), i.e. a value of $S S A$ equal to 1 indicates a purely scattering aerosol. SSA was calculated by dividing the scattering coefficient by the sum of the scattering and absorption coefficients. The $S A E$ describes the wavelength dependence of the aerosol scattering coefficient and can be interpreted as a measure of particle size, where larger particles have smaller $S A E$ values (Delene and Ogren, 2002). We calculated $S A E$ based on the following Eq. 1:

$285 S A E=-\frac{\log \left(\sigma s p_{450}\right)-\log \left(\sigma s p_{550}\right)}{\log \left(\lambda_{450}\right)-\log \left(\lambda_{550}\right)}$ Equation 1

where $\sigma_{s p}$ is the scattering coefficient at the indicated wavelength $(\lambda)$. Values below $0.045 \mathrm{Mm}^{-1}$ for $\sigma_{s p}$ were not used in the calculation of the $S A E$ since they were found to be close to detection limit.

Not all species are available for every station. Table 2 gives an overview of the variables and the periods for which they were obtained at each station. 
Table 1: Overview over methods applied to derive aerosol properties and the respective data sources

\begin{tabular}{|c|c|c|c|c|}
\hline Station & Variables & Method & Remark & Data Source \\
\hline \multirow[t]{5}{*}{ Alert } & $\begin{array}{l}\mathrm{SO}_{4}{ }^{2-}, \mathrm{NO}_{3}{ }^{-}, \\
\mathrm{NH}_{4}{ }^{+}, \mathrm{MSA}, \\
\mathrm{Na}^{+}, \mathrm{K}^{+}\end{array}$ & $\begin{array}{l}\text { HI-volume sampler, } \\
\text { ion chromatography, }\end{array}$ & $\begin{array}{l}\text { Total suspended } \\
\text { particulates (TSP) }\end{array}$ & $\begin{array}{l}\text { EBAS* } \\
\text { (Sharma et al., 2019) }\end{array}$ \\
\hline & EBC & Aethalometer AE06 & $880 \mathrm{~nm}, \mathrm{TSP}$ & $\begin{array}{l}\text { EBAS } \\
\text { (Sharma et al., 2019) }\end{array}$ \\
\hline & $\mathrm{Ca}^{2+}, \mathrm{Fe}$ & $\begin{array}{l}\text { Instrumental neutron } \\
\text { activation analysis } \\
\text { (INAA), inductively } \\
\text { coupled plasma mass } \\
\text { spectrometry (ICP- } \\
\text { MS) }\end{array}$ & $\begin{array}{l}\text { TSP } \\
\text { INAA: } 1988-2013 \\
\text { for Ca } \\
\text { ICP: } 1980-1997 \\
\text { for Ca, } 1980-2007 \\
\text { for Fe, } \\
\text { data were averaged } \\
\text { when both methods } \\
\text { are available }\end{array}$ & (Sharma et al., 2019) \\
\hline & $\begin{array}{l}\text { Scattering } \\
\text { coefficient }\end{array}$ & $\begin{array}{l}\text { Nephelometer (TSI } \\
3563 \text { ) }\end{array}$ & $\begin{array}{l}550 \mathrm{~nm}, \text { particulate } \\
\text { matter }<1 \mu \mathrm{m} \\
\left(\mathrm{PM}_{1}\right)\end{array}$ & $\begin{array}{l}\text { S. Sharma, personal } \\
\text { communication }\end{array}$ \\
\hline & $\begin{array}{l}\text { Absorption } \\
\text { coefficient }\end{array}$ & $\begin{array}{l}\text { Particle soot } \\
\text { absorption } \\
\text { photometer, } \\
\text { continuous light } \\
\text { absorption } \\
\text { photometer } \\
\text { (PSAP/CLAP) } \\
1 \lambda \text { and } 3 \lambda\end{array}$ & $\begin{array}{l}\mathrm{PM}_{1} \text {, converted to } \\
550 \mathrm{~nm} \text { (via inverse } \\
\text { wavelength } \\
\text { relation) }\end{array}$ & $\begin{array}{l}\text { S. Sharma, personal } \\
\text { communication }\end{array}$ \\
\hline
\end{tabular}




\begin{tabular}{|c|c|c|c|c|}
\hline Barrow & $\begin{array}{l}\mathrm{SO}_{4}^{2-}, \mathrm{NO}_{3}^{-} \\
\mathrm{NH}_{4}^{+}, \mathrm{MSA} \\
\mathrm{Na}^{+}, \mathrm{K}^{+}\end{array}$ & $\begin{array}{l}\text { Ion chromatography, } \\
\mathrm{PM}_{1} \\
\text { (supermicron data } \\
\text { are also available but } \\
\text { were not used here) }\end{array}$ & & $\begin{array}{l}\text { (Quinn et al., 2007), } \\
\text { submicron : } \\
\text { https://data.pmel.noaa.gov/pm } \\
\text { el/erddap/tabledap/submicron. } \\
\underline{\text { html }}\end{array}$ \\
\hline & EBC & $\begin{array}{l}\text { Aethalometer and } \\
\text { PSAP }\end{array}$ & $\begin{array}{l}\text { PM }_{10,} \text { measured or } \\
\text { converted to } 880 \\
\text { nm, } \\
\text { AE8 until } 2001 \text {, } \\
\text { PSAP } 1 \lambda 2001 \text { - } \\
2006, \text { PSAP } 3 \lambda \\
2006 \text { - } 2010, \text { AE31 } \\
\text { from } 2010-2016, \\
\text { AE33 after } 2016\end{array}$ & $\begin{array}{l}\text { (Sharma et al., 2013), and for } \\
\text { newer values } \\
\text { personal communication E. } \\
\text { Andrews }\end{array}$ \\
\hline & $\begin{array}{l}\text { Scattering } \\
\text { coefficient }\end{array}$ & $\begin{array}{l}\text { Nephelometer (TSI } \\
3563 \text { ) }\end{array}$ & $550 \mathrm{~nm}, \mathrm{PM}_{10}$ & EBAS \\
\hline & $\begin{array}{l}\text { Absorption } \\
\text { coefficient }\end{array}$ & PSAP, CLAP & $\begin{array}{l}\mathrm{PM}_{10}, \\
1 \lambda \text { PSAP 1997- } \\
2006 \\
3 \lambda \text { PSAP } 2006- \\
2014 \\
3 \lambda \text { CLAP } 2014 \text { - } \\
\text { present, converted } \\
\text { to } 550 \mathrm{~nm}\end{array}$ & EBAS \\
\hline \multirow[t]{3}{*}{ Zeppelin } & $\begin{array}{l}\mathrm{SO}_{4}^{2-}, \mathrm{MSA}, \\
\mathrm{Na}^{+}, \mathrm{Ca}^{2+}, \mathrm{K}^{+}\end{array}$ & Ion chromatography & $\mathrm{PM}_{10}$ & (Sharma et al., 2012) \\
\hline & EBC & $\begin{array}{l}\text { Aethalometer } \\
\text { (AE31) }\end{array}$ & $880 \mathrm{~nm}, \mathrm{TSP}$ & $\begin{array}{l}\text { personal communication: K. } \\
\text { Eleftheriadis, and } \\
\text { (Eleftheriadis et al., 2009) }\end{array}$ \\
\hline & $\begin{array}{l}\text { Scattering } \\
\text { coefficient }\end{array}$ & $\begin{array}{l}\text { Nephelometer (TSI } \\
3563 \text { ) }\end{array}$ & TSP & (Heslin-Rees et al., 2020) \\
\hline
\end{tabular}




\begin{tabular}{|c|c|c|c|c|}
\hline Villum & $\begin{array}{l}\mathrm{SO}_{4}^{2-}, \mathrm{NO}_{3}^{-} \\
\mathrm{NH}_{4}^{+}, \mathrm{Na}^{+}, \mathrm{K}^{+} \\
\mathrm{Ca}^{2+}\end{array}$ & $\begin{array}{l}\text { Ion chromatography, } \\
\text { proton induced X-ray } \\
\text { emission (PIXE), } \\
\text { ICP-MS }\end{array}$ & $\begin{array}{l}\mathrm{SO}_{4}^{2-}, \mathrm{NO}_{3}^{-}, \mathrm{NH}_{4}^{+}, \\
\mathrm{Na}^{+} \text {: Ion } \\
\text { chromatography } \\
\text { PIXE: } 1990-2009 \\
\text { for K}{ }^{+}, \mathrm{Ca}^{2+} \\
\mathrm{ICP}-\mathrm{MS}: 2011- \\
2017 \text { for } \mathrm{K}^{+}, \mathrm{Ca}^{2+} \\
\text { TSP }\end{array}$ & $\begin{array}{l}\text { A. Massling, personal } \\
\text { communication }\end{array}$ \\
\hline \multirow[t]{2}{*}{ Gruvebadet } & $\begin{array}{l}\mathrm{SO}_{4}{ }^{2-}, \mathrm{NO}_{3}{ }^{-}, \\
\mathrm{MSA}\end{array}$ & Ion chromatography, & $\mathrm{PM}_{10}$ & $\begin{array}{l}\text { R. Traversi, personal } \\
\text { communication } \\
\text { (Becagli et al., 2019, 2016) }\end{array}$ \\
\hline & EBC & PSAP $3 \lambda$ & TSP & (Gilardoni, 2019) \\
\hline Kevo & EBC & $\begin{array}{l}\text { Thermal optical } \\
\text { methods }\end{array}$ & TSP & (Dutkiewicz et al., 2014) \\
\hline \multirow[t]{3}{*}{ Tiksi } & $\mathrm{EBC}$ & $\begin{array}{l}\text { Aethalometer } \\
\text { (AE31) }\end{array}$ & $880 \mathrm{~nm}, \mathrm{PM}_{10}$ & EBAS \\
\hline & $\begin{array}{l}\text { Scattering } \\
\text { coefficient }\end{array}$ & $\begin{array}{l}\text { Nephelometer (TSI } \\
3563 \text { ) }\end{array}$ & $\begin{array}{l}550 \mathrm{~nm} \text {, ambient } \\
\text { humidity, } \mathrm{PM}_{10}\end{array}$ & EBAS \\
\hline & $\begin{array}{l}\text { Absorption } \\
\text { coefficient }\end{array}$ & $\begin{array}{l}\text { Aethalometer } \\
\text { (AE31) }\end{array}$ & $\begin{array}{l}\text { converted to } 550 \\
\mathrm{~nm}, \mathrm{PM}_{10}\end{array}$ & EBAS \\
\hline Thule & $\begin{array}{l}\mathrm{SO}_{4}^{2-}, \mathrm{NO}_{3}^{-} \\
\mathrm{MSA}\end{array}$ & Ion chromatography & $\mathrm{PM}_{10}$ & (Becagli et al., 2019) \\
\hline \multirow[t]{2}{*}{ Summit } & $\begin{array}{l}\text { Scattering } \\
\text { coefficient }\end{array}$ & $\begin{array}{l}\text { Nephelometer (TSI } \\
3563 \text { ) }\end{array}$ & $550 \mathrm{~nm}, \mathrm{PM}_{2.5}$ & EBAS \\
\hline & $\begin{array}{l}\text { Absorption } \\
\text { coefficient }\end{array}$ & CLAP-3 $\lambda$ & $550 \mathrm{~nm}, \mathrm{PM}_{2.5}$ & EBAS \\
\hline Pallas & $\begin{array}{l}\text { Scattering } \\
\text { coefficient }\end{array}$ & $\begin{array}{l}\text { Nephelometer (TSI } \\
3563 \text { ) }\end{array}$ & $\begin{array}{l}550 \mathrm{~nm}, \text { TSP until } \\
2008, \text { from } 2008 \\
\mathrm{PM}_{10}\end{array}$ & EBAS \\
\hline
\end{tabular}




\begin{tabular}{|l|l|l|l|l|}
\hline & $\begin{array}{l}\text { Absorption } \\
\text { coefficient }\end{array}$ & $\begin{array}{l}\text { MAAP } \\
\text { (Thermo_5012) }\end{array}$ & $637 \mathrm{~nm}^{* *}, \mathrm{PM}_{10}$ & EBAS \\
\hline
\end{tabular}

* ebas.nilu.no/

** Converted to $550 \mathrm{~nm}$ based on equation 5 in Schmeisser et al. (2018) and assuming the Ångström exponent to be equal to one.

\subsection{Annual cycles and trend calculations}

For the annual cycles, we calculated the median and interquartile range from all data points per month for

the available periods. To derive the anomaly, we subtracted the overall median value and normalized by the overall interquartile range. The overall values are based on all data entries available for the given time period. They are shown in the box plots in Figure 2. Note that data for Gruvebadet is not available for all winter months.

We derived long-term trends for all variables, where data from at least five consecutive years were available. Trends are calculated for the haze season (January, February, March, April, JFMA) and the summer season (June, July, August, September, JJAS) following the example of Quinn et al. (2009) for data obtained at Barrow. This allows for comparison with previously derived trends for aerosol properties at Arctic stations. The haze season is dominated by anthropogenic emissions, while the summer season reflects a mix of anthropogenic and natural emissions. The seasonal separation hence allows tracking the evolution of anthropogenic and natural influences more specifically. It also avoids the need for prior deseasonalization of the data. Note, for MSA, we divided the seasons into April-May, and June-August, because there were not enough data above the detection limit before and after. A similar approach to separate data to derive seasonal trends has been introduced by Hirsch et al. (1982). Trend significance was tested with the non-parametric Mann-Kendall test on each season. Non-parametric means that no

315 prior assumption of a specific distribution is necessary. The test has been widely applied to environmental data sets including in the Arctic (Tunved and Ström, 2019; Skov et al., 2020; Heslin-Rees et al., 2020; Collaud Coen et al., 2020b, a), not least because of its non-parametric nature and its tolerance of missing 
values. The null hypothesis of the test is that no trend exists. We defined a trend to be significant if the pvalue is smaller or equal to 0.05 (green dots and upward pointing arrows in Table 2). Trends with a pvalue between 0.05 and 0.1 are marked orange and larger values (p-value >0.1) in red (Table 2). The results of the Mann-Kendall test are strongly dependent on autocorrelation, whereby a positive autocorrelation increases the likelihood that a trend is determined when there is none (Kulkarni and von Storch, 1995). To avoid an autocorrelation signal, and to accommodate the highly diverse time resolution of the data set, we calculate seasonal median values. The slopes of the trends were calculated using the

325 Theil-Sen slope estimator, another non-parametric method. Significance and slope were derived for entire time series and on a decadal basis. Values for specific decades allow for intercomparison between variables and stations. However, decadal values are also given if there are at least five consecutive years of data within a decade. Hence the time periods within decades are not equal in all cases and for all stations. Table 2 shows with the grey bars for which years which variables are available per station. At Villum, a large time gap exists between 2003 and 2007. We derived trends separately for before and after the gap.

It is important to note that the Mann-Kendall test requires a monotonic trend for the time period over which it is calculated. This is often the case for anthropogenic tracers during the haze season. However, some variables do not show a monotonic behavior. For example, at Alert MSA exhibited a significant negative trend between 1981 and 1999 and a non-significant positive trend thereafter (Sharma et al., 2019). To reflect this, we split the data set and calculated trends separately.

\section{Results}

\subsection{Annual cycles}

\subsubsection{Chemical composition}

340 Figure 2 shows the statistical distribution of concentrations per chemical species, as box plots for each station on the right side and as monthly anomalies of the normalized concentrations as annual cycles on the left side. 
$\mathrm{SO}_{4}{ }^{2-}$ makes up the highest concentrations at each station with medians between 0.1 and $0.3 \mu \mathrm{g} \mathrm{m}^{-3}$, followed by $\mathrm{Na}^{+}\left(0.05\right.$ to $\left.0.15 \mu \mathrm{g} \mathrm{m}^{-3}\right)$. $\mathrm{NH}_{4}{ }^{+}, \mathrm{NO}_{3}{ }^{-}, \mathrm{EBC}, \mathrm{Fe}$ and $\mathrm{nssCa}^{2+}$ all range between 0.01 and 0.06 $\mu \mathrm{g} \mathrm{m}^{-3}$. $\mathrm{NssK}^{+}$and MSA exhibit smaller concentrations between 0.003 and $0.015 \mu \mathrm{g} \mathrm{m}^{-3}$. EBC, $\mathrm{SO}_{4}^{2}$, $\mathrm{NO}_{3}{ }^{-}$and $\mathrm{NH}_{4}{ }^{+}$are typical anthropogenic tracers during the Arctic haze season where the highest levels are observed. Their dominant sources in the mid-latitudes are fossil fuel combustion $\left(\mathrm{EBC}, \mathrm{SO}_{4}{ }^{2-}, \mathrm{NO}_{3}{ }^{-}\right)$, residential heating $(\mathrm{EBC})$ and agriculture $\left(\mathrm{NH}_{4}{ }^{+}\right)(\mathrm{AMAP}, 2015)$. With regards to $\mathrm{EBC}$, Tiksi $\left(71^{\circ} \mathrm{N}\right)$ and Kevo $\left(69.4^{\circ} \mathrm{N}\right)$ experience the highest concentrations and the largest variability, likely a result of their proximity to both anthropogenic source regions and potential local influences as well. The annual cycles are similar for all stations showing the typically elevated concentrations during the haze period, however, Zeppelin experiences relatively lower concentrations in January and February. This is likely related to stronger influence of precipitation on the particles concentrations, because the island of Svalbard experiences the precipitation maximum during winter, in contrast to all other regions in the Arctic, where the maximum precipitation occurs in (late) summer (Freud et al., 2017).

Alert, Zeppelin, Barrow and Villum are comparable in their $\mathrm{SO}_{4}{ }^{2-}$ concentrations and variability. The four stations show almost identical annual cycles with the characteristic haze peak in late winter/early spring and the minimum in summer. Thule and Gruvebadet show a more pronounced relative increase in April. $\mathrm{NH}_{4}{ }^{+}$and $\mathrm{SO}_{4}{ }^{2-}$ are very similar in their annual cycles, which is consistent with the formation of ammonium sulfate or ammonium bisulfate. At Barrow $\mathrm{NH}_{4}{ }^{+}$concentrations are roughly twice as high as at Alert and Villum, indicating higher availability of $\mathrm{NH}_{4}{ }^{+}$and less acidic particles since the $\mathrm{SO}_{4}{ }^{2-}$ concentrations are similar at all three stations. At Villum and Alert, ammonium's statistical distribution is almost identical. $\mathrm{NO}_{3}{ }^{-}$concentrations are higher than those of $\mathrm{NH}_{4}{ }^{+}$at these two stations and variable. This could be related to atmospheric chemical processes of particulate $\mathrm{NO}_{3}{ }^{-}$formation, which depends on the aerosol acidity, water content and ambient temperature (see the discussion of the long-term trends for more details). 

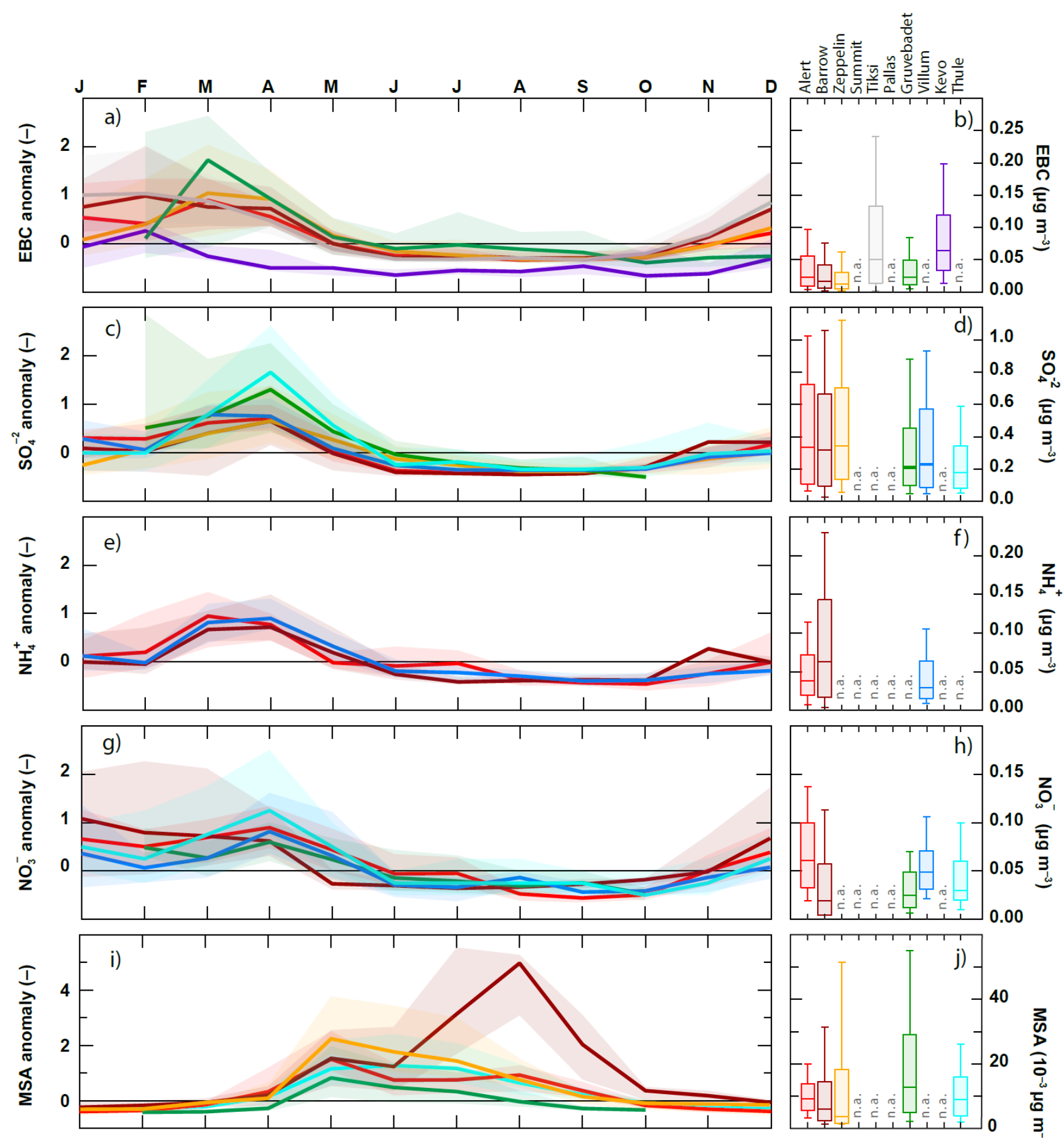

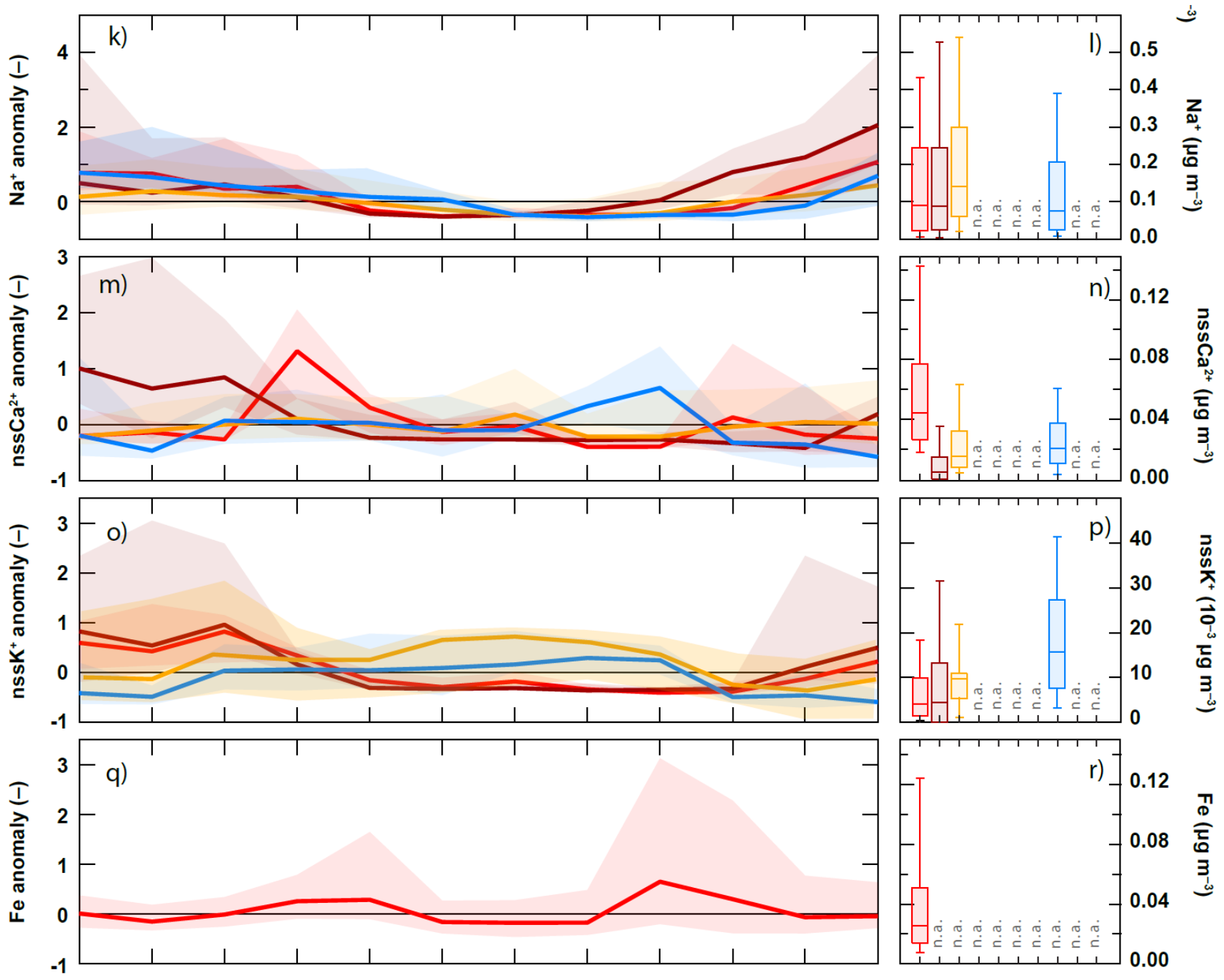

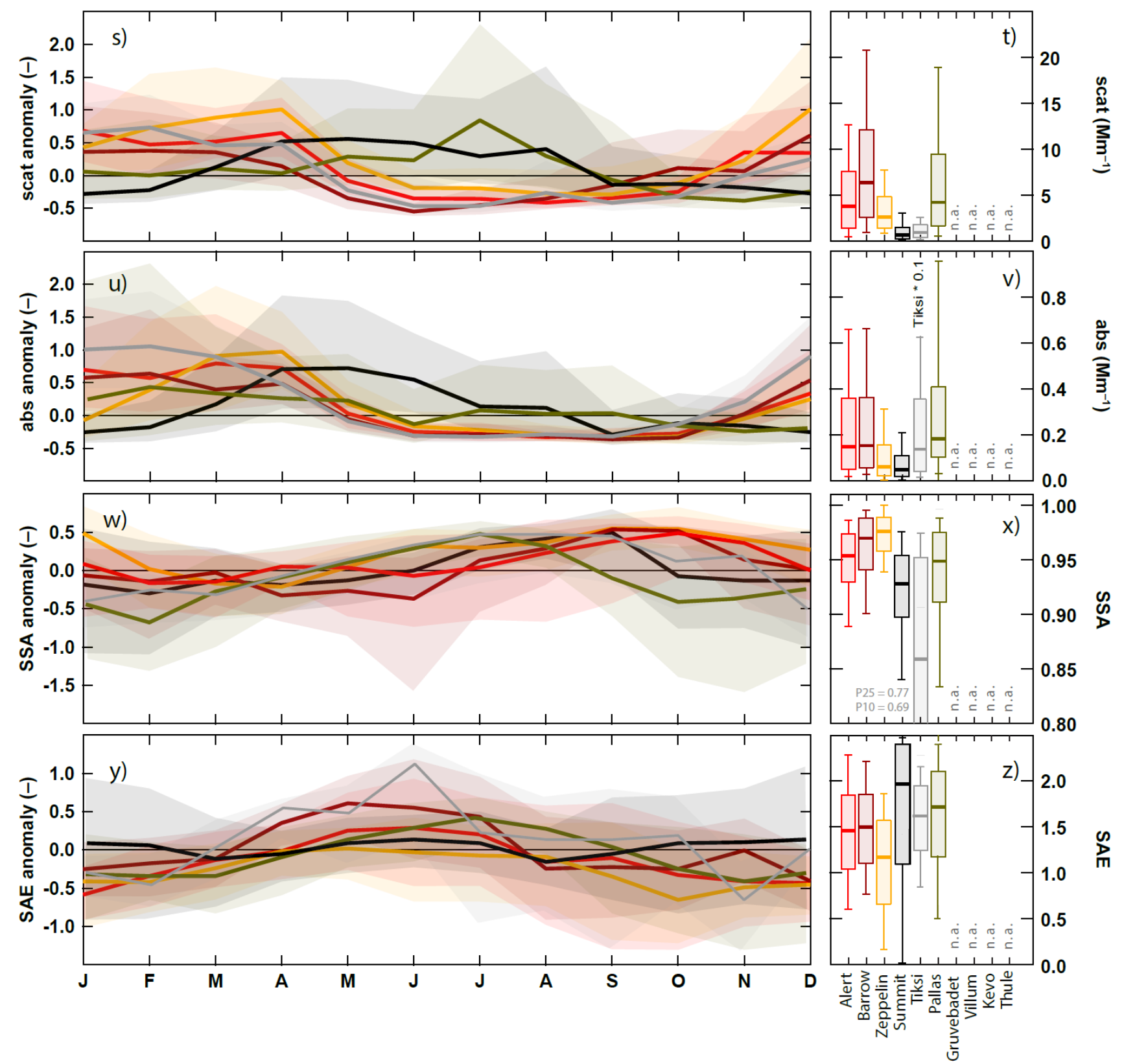

Figure 2: The left column shows annual cycles of aerosol chemical compounds and physical properties for each available data set as anomaly. The data are normalized by the median and interquartile range (see Methods). Colors represent stations given in the right column of the figure (see panel b). The right column provides statistical values (median, interquartile range and $10^{\text {th }}$ and $9^{\text {th }}$ percentiles) per variables and station. Chemical compounds were derived from the following size ranges (see also Table 1): TSP for Alert and Villum, $\mathrm{PM}_{10}$ for Zeppelin, and PM $\mathrm{PM}_{1}$ for Barrow. 
The other chemical tracers are less uniformly distributed throughout the year and there are significant differences among the stations. MSA is an oxidation product formed from DMS, which is derived from marine algae. It is hence associated with the presence of open water (or marginal sea ice zones), nutrients, sunlight and DMS producing algae as is reflected in the annual cycle. At all stations, a characteristic spring bloom peak in April-May is visible (Becagli et al., 2019; Moffett et al., 2020). In August, Barrow features a second and even higher peak, likely influenced by regional phytoplankton blooms (Moffett et al., 2020; Quinn et al., 2002). The other three stations do not show such strong signals and their highest MSA peaks are confined to spring, when southerly air masses transport MSA from productive waters in the mid-latitudes (Sharma et al., 2019).

Another natural contribution to aerosol is $\mathrm{Na}^{+}$, which originates from sea spray and salt-laden blowing snow. The annual cycles at Alert and Barrow are similar with highest concentrations in winter, which is evidence of mixed contributions from blowing snow (Huang and Jaeglé, 2017) and southerly advection of sea spray (Quinn et al., 2002). Zeppelin shows lower enhancement during winter likely because of its elevation (476 m a.s.l). Villum features an annual cycle very similar to Alert, albeit with less enhancement in between November and December.

$\mathrm{NssCa}^{2+}$ and $\mathrm{Fe}$ have been used as mineral and soil dust tracer by Sharma et al. (2019) for Alert, where they show a spring and autumn peak. The spring peak has been interpreted as long-range transported dust from Asian deserts based on a Lagrangian model study (Groot Zwaaftink et al., 2016), whereas the autumn peak corresponds to minimum snow coverage and hence potential local soil dust sources. The latter could also be the case for Villum for nssCa ${ }^{2+}$, where the main peak occurs in autumn, but the actual source is difficult to pinpoint (Nguyen et al., 2013; Heidam et al., 2004). Barrow exhibits a strong $\mathrm{nssCa}^{2+}$ enhancement between January and February, which has been interpreted as a signal of long-range transported dust from Eurasia (Quinn et al., 2002). At Zeppelin the annual cycle does not show any pronounced features.

$\mathrm{NssK}^{+}$can be interpreted as biomass burning tracer originating from domestic wood burning, agricultural or forest fires contributing during different times of the year. At Alert and Barrow the annual cycle of $\mathrm{nssK}^{+}$is similar to that of typical anthropogenic tracers, e.g., EBC, and has been identified as a haze tracer at Barrow by Quinn et al. (2002). Based on carbon isotope measurements and Lagrangian dispersion 
modeling it has been shown that domestic wood burning is an important source of black carbon in winter (Stohl et al., 2013; Winiger et al., 2019). Hence, it is conceivable that nssK ${ }^{+}$could also be an indication of domestic wood burning. However, at Villum nssK ${ }^{+}$has been found to originate potentially also from fossil fuel burning (Nguyen et al., 2013; Heidam et al., 2004). The seasonal cycle of nssK ${ }^{+}$at Villum shows a late summer enhancement from soil dust (Heidam et al., 2004). At Zeppelin nssK ${ }^{+}$remains enhanced throughout May to September. The presence of $\mathrm{nssK}^{+}$and its interpretation as biomass burning marker is in agreement with carbon isotope source apportionment by Winiger et al. (2019), who show an elevated level of $60 \%$ biomass burning contribution to black carbon at the station. It has been shown for Zeppelin that long-range transport of agricultural fires can have a strong impact on the aerosol population in spring (Stohl et al., 2007).

\subsubsection{Optical properties}

Figure 2 also shows aerosol optical properties, which are tightly linked to the chemical composition and absolute aerosol mass for the scattering and absorption coefficients. Similar figures showing the absolute values as annual cycles have been discussed in Schmeisser et al. (2018) for data between 2012 and 2014 , and by Quinn et al. (2002) and Delene and Ogren (2002) for Barrow for 1997 to 2000. Here, we show all data available to this study (see Table 2). The annual cycle of $\sigma_{s p}$ reflects the higher aerosol burden during the haze season and the low concentrations during summer for the observatories at Alert, Barrow, Zeppelin and Tiksi. Pallas and Summit exhibit an opposite behavior with peak values in spring and summer, respectively. Pallas, being located relatively far south is much more influenced by Eurasian anthropogenic emissions being downwind (easterlies prevail) of significant emission sources (Aalto et al., 2002; Asmi et al., 2011) and also by biogenic emissions from the surrounding boreal forest (Hyvärinen et al., 2011; Tunved et al., 2006). Summit is located $3238 \mathrm{~m}$ a.s.l. and is therefore not affected by winter haze, which manifests itself in the lower layers of the atmosphere. It is however subject to long-range transport of biomass burning and anthropogenic emissions during spring and summer (Schmale et al., 2011; Thomas et al., 2017; Stohl et al., 2006). The $\sigma_{a p}$ is closely related to EBC (and correlated 1:1 for all stations where EBC was derived with a uniform mass absorption cross section, except at Kevo where a 
thermal-optical method was used) and both variables follow a similar annual cycle (Figure 2, panels a, u) with the maximum values during the haze period at Alert, Barrow, Tiksi and Zeppelin. Summit shows much lower $\sigma_{a p}$ values and follows a different annual cycle with a maximum in spring and summer, comparable to the observation of $\sigma_{s p}$. Here again, the influence of long-range transported biomass burning emissions as well as emissions from other anthropogenic sources that can reach Summit throughout spring and summer is evident as well as the absence of haze pollution in winter. SSA, an inherent aerosol property independent of the absolute abundance of aerosol observed at Alert, Barrow, Zeppelin, Tiksi, Pallas and Summit, peaks in autumn and reflects the minimum in the $\sigma_{a p}$ during that time of the year. At Pallas SSA peaks earlier in summer than at the other stations and also drops more strongly during winter, likely due to the anthropogenic influence in winter and the stronger boreal forest contribution in summer. The lower SSA at Summit in autumn compared to the other stations has been interpreted by Schmeisser et al. (2018) as a darker background aerosol due to increased local air traffic from the station (despite a pollution sector controlled data product). SAE, another intensive property, behaves similarly at all six stations (Alert, Pallas, Summit, Barrow, Tiksi, and Zeppelin) with a peak in spring lasting through early summer. Given that larger $S A E$ values are indicative of smaller particle diameters, this behavior is in agreement with the annual cycle of the particle number size distributions as discussed e.g., in Croft et al. (2016) and Freud et al. (2017) due to the absence of larger submicron modes. During the $S A E$ peak, more frequent new particle formation enhances the Aitken mode population, while regular wet deposition depletes the coarser particles acting as cloud condensation nuclei (Freud et al., 2017).

\subsection{Trend calculations based on Mann-Kendall and Theil-Sen's Slope}

Table 2 gives an overview of the calculated trends and their significance for all stations and parameters.

455 The left part of the table provides the significance of the overall trend as a numeric value and optically by a colored marker (green means significant, see Methods) split by haze (JFMA) and summer (JJAS) seasons. An upward or downward pointing arrow, only for significant trends, represents the direction of the slope and the value indicates the change per year in the unit of the variable as indicated in the leftmost column. To the right the duration of the measurements are shown as grey bars, and within each decade 
460 the marker and arrow indicate the decadal trends and their significance. Numerical values are given in SI Table S1. Generally, the optical property records represent the last two decades and are shorter than chemical records at several stations, which date back about three decades. For MSA, the record across stations is fragmented, with only Alert and Barrow providing decadal information.

465 Table 2. Data coverage and trends. The grey bars on the right side indicate data availability per station and variable. The p-values and slopes on the left side indicate the overall trends characteristics per station and variables separated by season (JFMA and JJAS). Round markers indicate the significance of the trend, where green corresponds to a p-value $<0.05$, orange to 0.05 $<$ p-value $<0.10$, and red p-value $>0.10$. The arrows indicate whether the trend is positive or 470 negative. Decadal trend significance and direction are given by markers only in the respective time period. The two left (right) symbols correspond to JFMA (JJAS). Chemical compounds were derived from the following size ranges (see also Table 1): TSP for Alert and Villum, PM $_{10}$ for Zeppelin, and PM1 for Barrow*. 


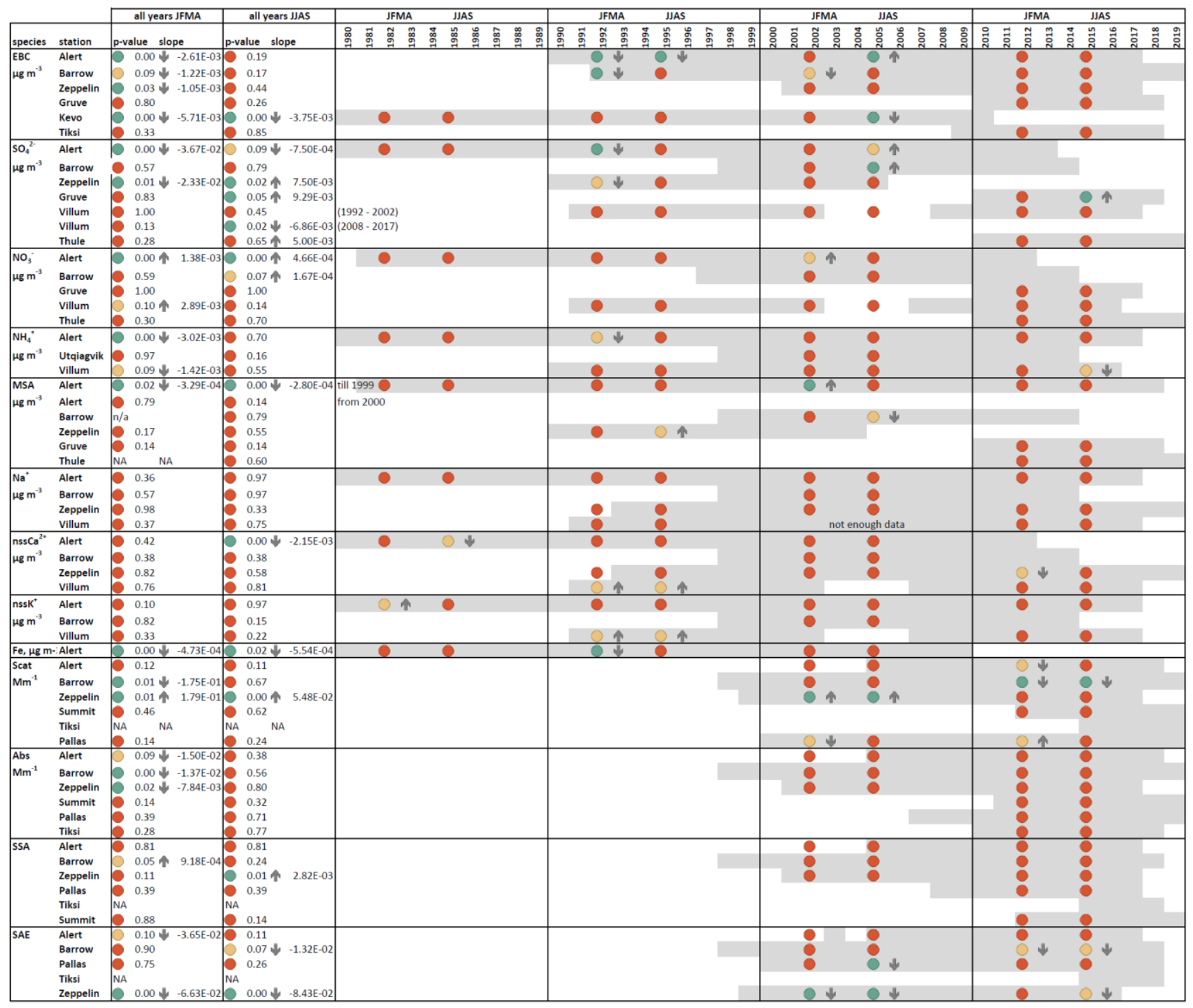

$\mathrm{n} / \mathrm{a}$ means there are not enough values above detection limit to calculate a p-value.

* For Barrow, optical property data go further back in time than shown here (see e.g., Collaud Coen et al., 2020b). Here, we use the same time series as shown in the AMAP report (2021), sind this work is based on it. 
J F M A
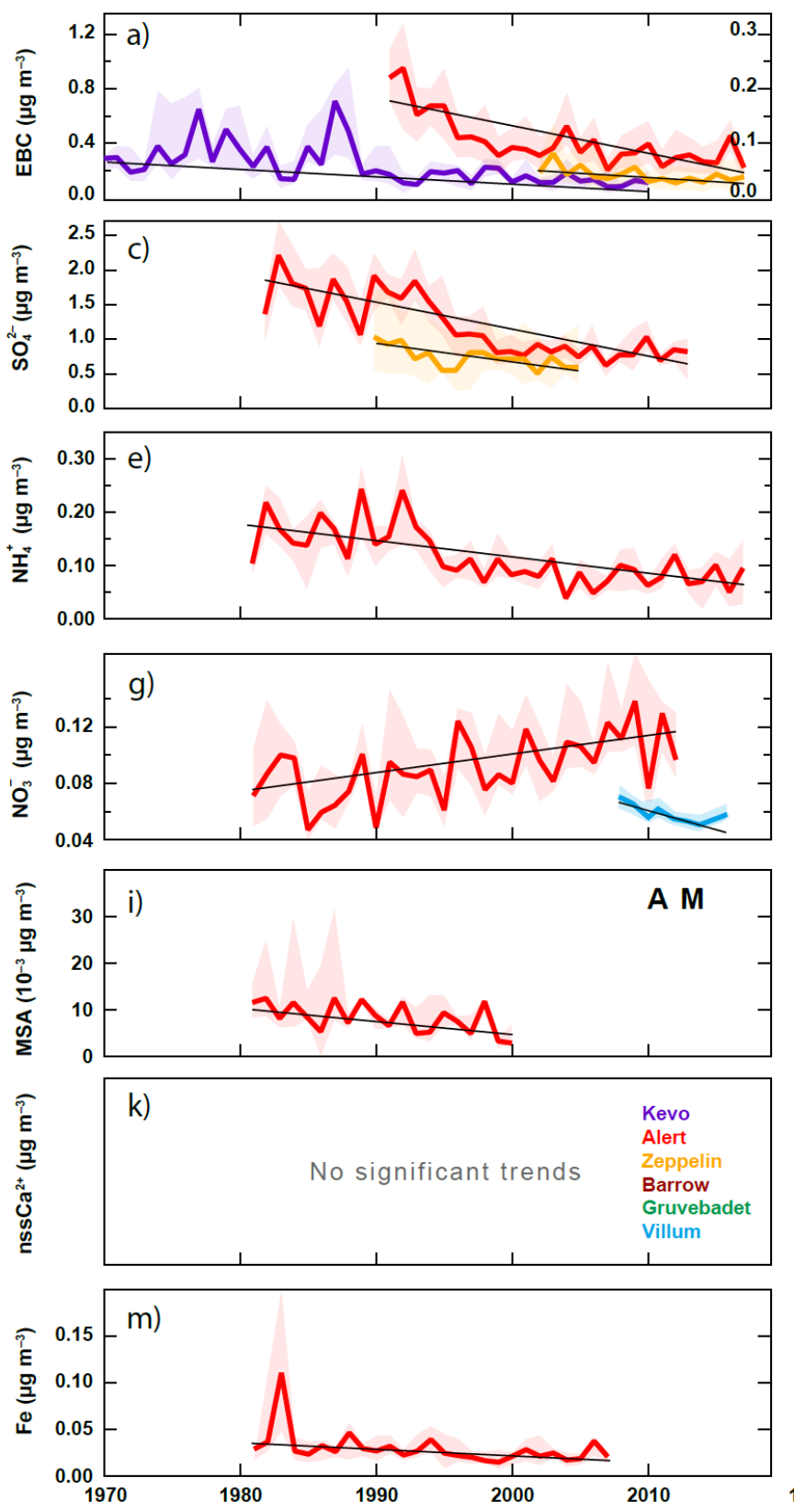

J J A S
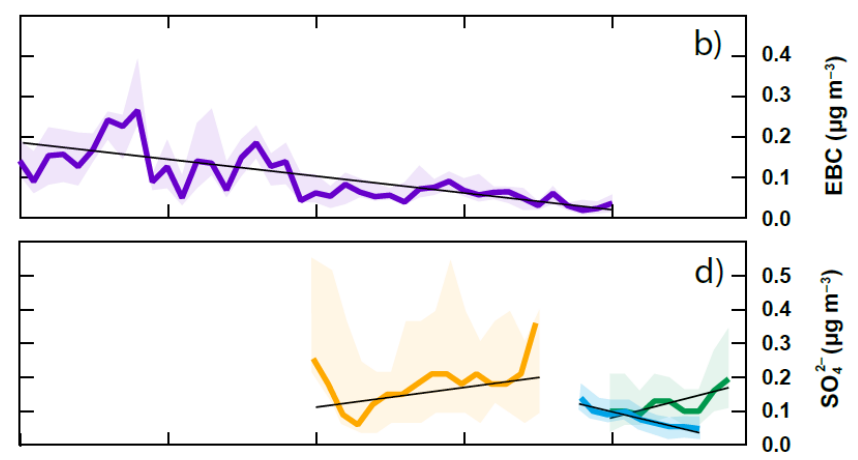

f)

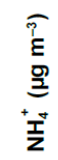
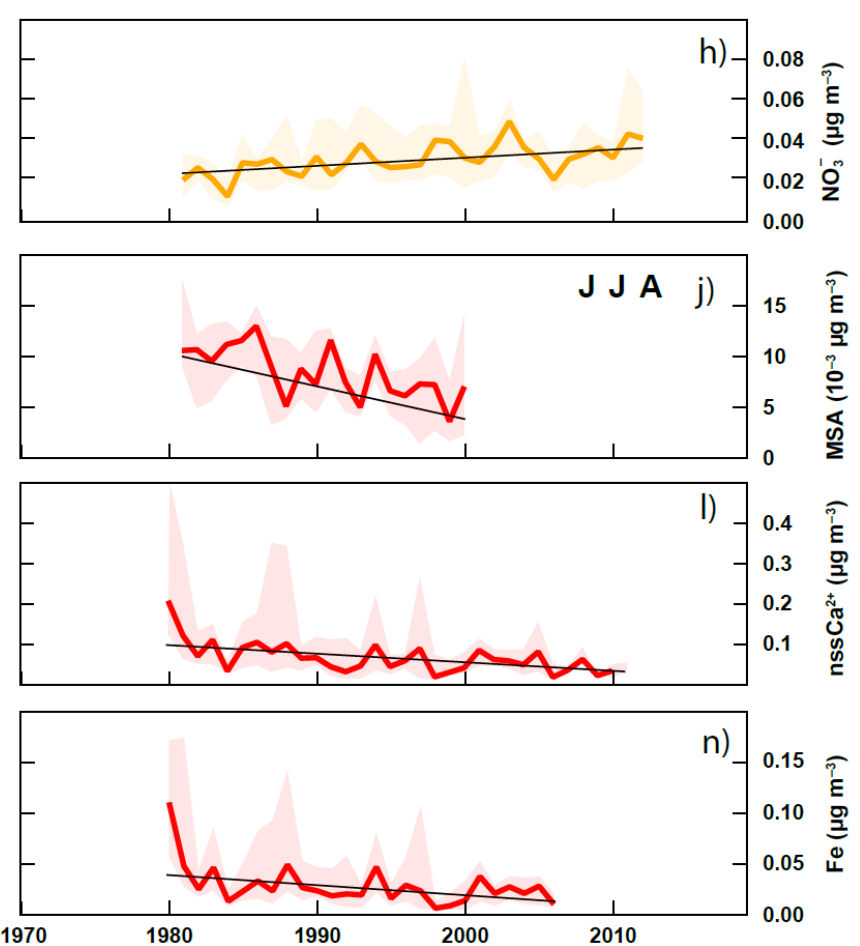
J F M A
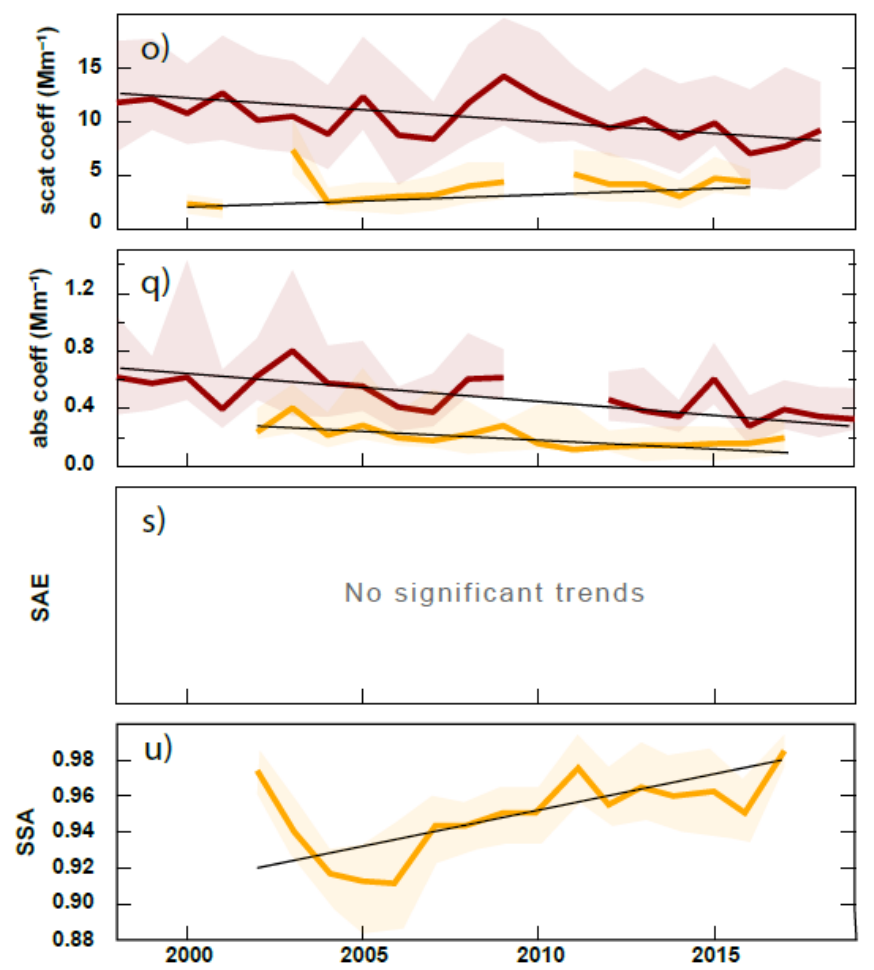

J J A S
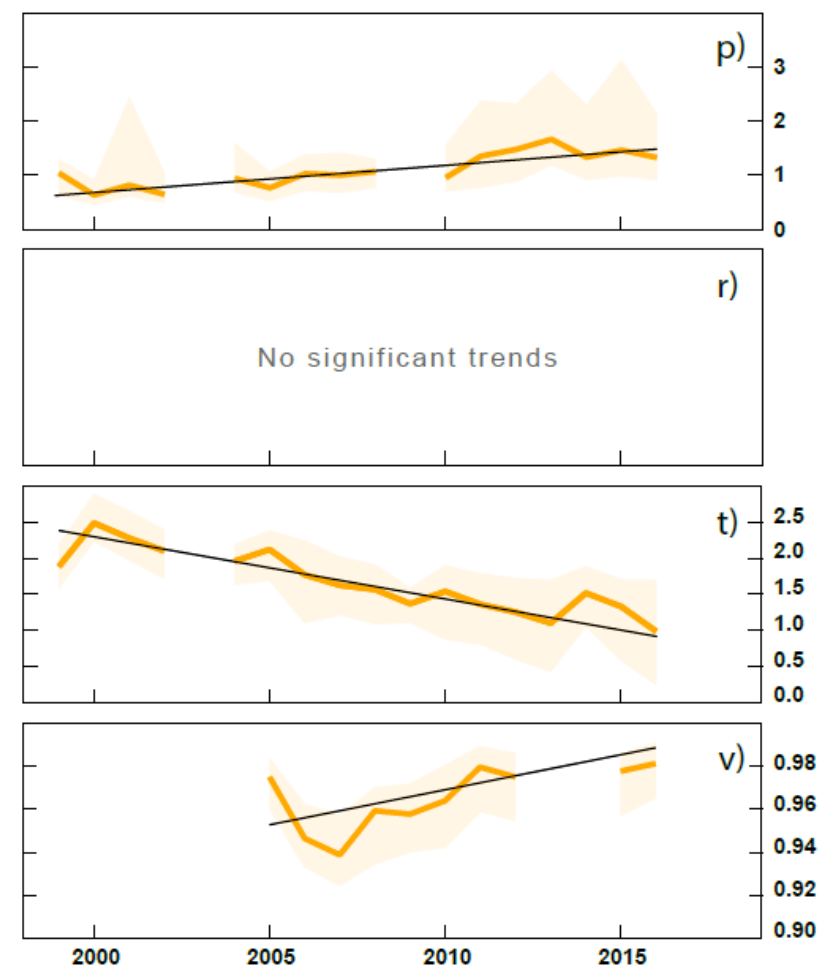

Figure 3: Significant trends $(\mathbf{p}<0.05)$ per variable and station for the entire time period over which data are available. For Villum we considered the time period 2007-2016 here. MSA is given for the months of April-May and June-July-August.

\subsubsection{Long-term trends of $\mathrm{SO}_{4}{ }^{2+}, \mathrm{NH}_{4}{ }^{+}, \mathrm{NO}_{3}{ }^{-}$and $\mathrm{EBC}$}

For the full period of each measurement, during the haze season $29 \%$ of the trends are significant $(\mathrm{p}<$ 0.05 ) with 13 negative, and three positive trends. For the summer, $21 \%$ of overall trends are significant with six negative and six positive trends. We show all 28 significant trends in Figure 3. In winter, typical haze tracers such as $\mathrm{EBC}, \mathrm{SO}_{4}{ }^{2-}$ and $\mathrm{NH}_{4}{ }^{+}$make up seven of the 13 significant and full period negative trends at Alert, Zeppelin, Villum and Kevo. This is consistent with the reduction of air pollution emissions in North America, Europe and Russia, which we show in Figure 4 based on the ECLIPSEv6b (HöglundIsaksson et al., 2020) and CMIP6 emission data between 1970 and 2014 (Hoesly et al., 2018). For BC, 495 the emissions data show a gradual decrease from 1970 to 2000 for the Western Arctic (Western Arctic 
refers to the USA and Canada), while emissions in the Eastern Arctic (Eastern Arctic refers to the Kingdom of Denmark, Finland, Iceland, Norway, the Russian Federation, and Sweden) and the rest of Europe show a strong decrease between 1990 and 2000. Asia (Japan, People's Republic of China, Republic of India, Republic of Korea, Republic of Singapore) shows a decrease in the 1990s and a subsequent increase since the early 2000s. The EBC trend at Kevo reflects the sharp decline in 1990, and also at Alert most of the EBC concentration decline happened before 2000, reflecting primarily the economic change in the former Soviet Union (Dutkiewicz et al., 2014; Sharma et al., 2019). However, a significant decadal winter trend is only visible for Alert and Barrow in the 1990s. Otherwise, decadal trends are not significant. Emissions in the 2000s were slightly on the rise for northern Eurasia and North America, and strongly elsewhere. Arctic EBC concentrations do not show a clear decline from 2000 onwards during winter, likely a result of the short period analyzed and the interannual variability.

To demonstrate the influence of short-term variability in the last decade on the significance of trends, we tested the required yearly rate of increase or decrease in EBC concentrations to detect a significant trend ( $\mathrm{p}$-value < 0.05) within the last ten or close to ten years of measurements at the following stations: Alert 510 (2007 - 2017), Zeppelin (2007 - 2017), Barrow (2009 - 2019), Gruvebadet (2011 - 2018), and Tiksi (2010 -2018). We calculated the trend line for the years given in parenthesis, de-trended the EBC concentration data with it and then added $\mathrm{x}_{\mathrm{i}} \%$ of EBC increase per year in steps of 1 (i.e. $\mathrm{x}_{1}=1 \%, \mathrm{x}_{2}=2 \%$ and so on) until the trend emerged as significant. The results for Alert and Zeppelin are $5 \% \mathrm{yr}^{-1}$, for Barrow $6 \%$ $\mathrm{yr}^{-1}$, for Tiksi $11 \% \mathrm{yr}^{-1}$, and for Gruvebadet $16 \% \mathrm{yr}^{-1}$. Hence, the present-day short-term variability 515 requires relatively large changes to occur to derive significant trends with the Mann-Kendall Theil-Sen method for time periods less than 10 years. This explains why trends on the order of $1 \%$ or less per year cannot be significant over single decades but are significant over a record of 20 or more years (as for the case of EBC at Zeppelin in winter, see Table 2). Therefore, even if none of the EBC trends in the haze season turned out to be significant for the 2010-2019 period (in contrast with previous decades), such "stagnation" must be considered carefully. In addition, detection of a $1 \%$ change would not reflect large changes in air quality. The absence of trend detection over shorter periods also highlights the importance of maintaining monitoring activities at the Arctic observatories in the long run, as decadal changes 
(occurring over periods of $>10$ years) in atmospheric composition can be detected with more statistical certainty.

$\mathrm{SO}_{2}$ emissions, a precursor to particulate $\mathrm{SO}_{4}{ }^{2-}$, decreased strongly in Europe and the Western Arctic countries since 1980, and showed a clear dip between 1990 and 2000 in the Eastern Arctic, probably due to the economic change in the former Soviet Union. Elsewhere emissions increased strongly, except for the late 1990s in Asia. Winter concentration trends at Alert and Zeppelin follow this pattern, showing the strongest decline in the 1990s and then leveling off. There is only one significant decadal wintertime trend for $\mathrm{SO}_{4}{ }^{2-}$, which occurred at Alert in the decade of the strongest $\mathrm{SO}_{2}$ emission reductions, 1990-2000. There are only few observations of $\mathrm{NH}_{4}{ }^{+}$, and only Alert shows a negative overall trend during the haze season. $\mathrm{NH}_{4}{ }^{+}$forms ammonium bisulfate and, to a lesser extent, ammonium sulfate in the particle phase and hence follows the trend of $\mathrm{SO}_{4}{ }^{2-}$. This is also observed at the other two stations that measured $\mathrm{NH}_{4}{ }^{+}$, Barrow and Villum, but the p-values do not indicate significance for the overall period $(0.05<\mathrm{p}$-value $<0.1)$.

$\mathrm{NO}_{3}{ }^{-}$shows opposing significant trends, i.e. positive at Alert and negative at Villum. It is important to keep in mind that Alert is the only site where a measurement record longer than 30 years has been acquired. For Villum the time span of data available (2007 to 2017) is short. The positive trend at Alert is opposite to the emission reduction efforts of $\mathrm{NO}_{\mathrm{x}}$ (see Figure 4), the precursor to $\mathrm{NO}_{3}{ }^{-}$. However, with the reduction in particle acidity, mainly caused by lower emissions of $\mathrm{SO}_{2}$ and subsequent formation of particulate sulfate, more particulate nitrate can be formed (Sharma et al., 2019). In addition, cold temperatures and high particle water content will favor the partitioning of nitrate into the aerosol phase (Guo et al., 2016; Shah et al., 2018). The analysis of $\mathrm{NO}_{3}{ }^{-}$clearly shows that not only emission changes are relevant for chemical trends of Arctic aerosols, but also the type of dominating chemical reactions that change due to an altered chemical composition of the atmosphere. Moreover, there seem to be different processes at play at different stations because Villum shows a different record compared to Alert. Some of the above discussed tracers also show significant trends during summer for the overall period. EBC decreased at Kevo, here again with almost a step change in the 1990s, due to the site's proximity to the former Soviet Union which collapsed in the 1990s. Sulfate decreased significantly at Villum over the periods from 2008 to 2017, however from 2010 to 2017 there is no significant trend. Thus, our primary 
conclusion is that the duration of observations is not long enough to show significant trends with the methods applied here. Enhanced microbial activity during the summer has been hypothesized to be a responsible factor for particle mass formation at Villum (Dall'Osto et al., 2018), even though the summer trend is negative. However, the aforementioned study focused on the smallest particles, while the filter based determination of $\mathrm{SO}_{4}{ }^{2-}$ targets the accumulation mode and even larger particles. Similar new particle formation studies have been conducted for Zeppelin and Gruvebadet (Becagli et al., 2019; Dall'Osto et al., 2017; Beck et al., 2020), where $\mathrm{SO}_{4}{ }^{2-}$ trends are positive and significant during summer. A plausibility check, on whether marine microbial activity is the driving factor, could be done using MSA concentrations. While those are not available at Villum, no significant trend in MSA has been found at Zeppelin station. The absence of an MSA trend might be an indication that reaction pathways are too complex to expect a directly measurable concentration effect in both particulate $\mathrm{SO}_{4}{ }^{2-}$ and MSA based on microbial activity. Also note that Villum is sea ice dominated for ten months of the year. Mahmood et al. (2019) found that enhanced microbial emissions can lead to higher CCN number concentrations which implies a subsequent removal of the corresponding emission products by wet deposition and hence might not be observed at permanent stations. The increase in $\mathrm{SO}_{4}{ }^{2-}$ around Svalbard is likely not due to increased shipping activities, e.g. from tourism. Eckhardt et al. (2013) show a strong influence in summer on sulfur from ships directly in Kongsfjorden, but on an annual basis this is a small effect. Moreover, recently new emission regulations require low sulfur-content fuel.

Particulate nitrate, consistent with the wintertime trends, shows a positive trend at Alert, where the

570 favored partitioning into the particle phase is likely the main reason also for the similar trend observed during summer at Alert. Generally, observatories that started measurements only after the year 2000, detect neither significant haze nor summer trends for anthropogenic tracers, because most of the air pollution reduction happened prior to that.

\subsubsection{Long-term trends of MSA, $\mathrm{Na}^{+}, \mathrm{nssK}^{+}, \mathrm{nssCa}^{2+}$, and $\mathrm{Fe}$}

The other chemical constituents, MSA, nssCa ${ }^{2+}$, and $\mathrm{Fe}$ are responsible for five significant trends, three in winter and two in summer. All are negative. Focusing on MSA first, interestingly, at Alert, which is the only station providing long-term continuous measurements of MSA, the concentrations of this ion 
show negative trends for the haze and summer seasons between 1980 and 1999. Here, the haze concentrations were related to long-range transport from more southerly latitudes, while the summer concentrations were related to more regional Arctic ocean sources (Sharma et al., 2019). Hence reasons for the two seasonal trends might be different and could reflect both variability in marine biological activity as well as long-range transport patterns and removal processes on route. Within the decade 2000 to 2010, the summer trend turns significant and positive as discussed in Sharma et al. (2012).The overall trend of MSA at Barrow in the haze season is negative for the period between 1998 and 2012 (not shown for reasons discussed below). The summer trend is not significant over this period at this station. Conversely, concentrations increased significantly at Barrow between 1999 and 2007 as discussed in Quinn et al. (2009). Note that they used July through September for the summer months, while here we use June through August. Thereafter, MSA concentrations drop until 2012. Calculating trends over the decade 2000 to 2010 hence results in no significant trend at Barrow (p-value of 0.09 and negative slope). This seeming contradiction is an important point, because the newly available longer time series shows that Quinn et al. (2009) described a development over a period which happened to show an increase, but which is not necessarily indicative of the longer-term trend. Recently the Barrow MSA time series was extended by Moffett et al. (2020) who found an overall positive trend for July through September between 1998 and 2017, further underlining the argument that trend calculations over different periods can lead to different results. This is particularly true for MSA concentrations which do not seem to follow a monotonic long-term trend, but instead show substantial variability over time scales of five to 15 years, which renders the Mann-Kendall approach inappropriate for further investigation. Note that these latest data from Moffett et al. (2020) were not available when this manuscript was being prepared.

$600 \mathrm{Na}^{+}$can also be regarded as a natural tracer, i.e. for sea spray its dominant source. No significant trend is observed, despite the fact that the potential for more sea spray aerosol formation due to retreating sea ice is often referred to in the literature (Browse et al., 2014; Struthers et al., 2011). However, not observing increased $\mathrm{Na}^{+}$concentrations does not mean that there is no enhanced sea spray production. Sea salt particles are efficient $\mathrm{CCN}$ and hence may preferentially be removed from the atmosphere by wet 605 deposition as has been shown for other hygroscopic substances (Mahmood et al., 2019), or air mass transport patterns can change. 
$\mathrm{NssCa}^{2+}$, a tracer for mineral and soil dust, shows a negative trend at Alert in summer, which is consistent with the results by Sharma et al. (2019). There is no evident explanation for the decrease, particularly given the decreasing snow cover and potential local sources of dust in late summer (see discussion of annual cycles). Sharma et al. (2019) hypothesize that long-range dust transport could play a role in this context. Iron is another dust tracer and exhibits a similar annual cycle compared to nssCa ${ }^{2+}$ at Alert, and the relative summer trend is also negative supporting the hypothesis of similar sources and or processes. However, the haze trend of $\mathrm{Fe}$ is also negative, while the $\mathrm{nsCa}^{2+}$ trend is not significant, indicating that, at least during winter, sources might be different for the two constituents. The shape of the long-term

615 trend curve of $\mathrm{Fe}$ is similar to that of $\mathrm{EBC}, \mathrm{SO}_{4}{ }^{2+}$ and $\mathrm{NH}_{4}{ }^{+}$, with the strongest decline in the mid-1990s. Given that $\mathrm{Fe}$ is emitted in fossil fuel combustion in addition to originating from soil dust (Matsui et al., 2018), this observation points towards an anthropogenic contribution to Fe observed at Alert.

No significant trend for $\mathrm{nssK}^{+}$was found. Given the recent increase in fire activity in the Arctic, one might have expected an emerging trend. Reasons for the absence of a trend may be that biomass burning emissions are carried further aloft in the troposphere and are not well captured at the surface, and that station records do not cover the last years, where the strongest emissions in consecutive years occurred (McCarty et al., 2021).

\subsubsection{Long-term trends of optical properties}

625 Aerosol optical properties, measured in situ at the surface, have also changed significantly at several stations during the last decades. Significant trends are observed in the scattering coefficient at Barrow and Zeppelin during winter, and at Zeppelin during summer with regard to the overall time period. At Barrow, the trend is negative during the haze period for all observations (1998-2019), and for both haze and summer seasons in the recent decade (2010-2019). Note that these overall and recent decreasing trends in scattering coefficient during winter are consistent with Collaud Coen et al. (2020b). However They did not find a significant trend in scattering coefficient during the summer months at Barrow for the most recent decade, though they used a different seasonal definitions. The scattering coefficient can be interpreted as a measure of the total measured aerosol concentrations and thus provides evidence of a decline in overall particulate matter, if hygroscopic growth or swelling is prevented through drying 
635 particles before measurements, which is the case at the discussed sites. At most stations, $\mathrm{Na}^{+}, \mathrm{SO}_{4}{ }^{2-}$ and organics make up most of the mass (Petäjä et al., 2020) and are also known to scatter light rather than absorb it. A direct comparison with the aerosol mass is difficult for Barrow, because most of the chemical and optical data only overlap between 1997-2013. In particular those species which contribute significantly to the mass, such as $\mathrm{Na}^{+}$and $\mathrm{SO}_{4}{ }^{2-}$, are relevant as has been shown by Quinn et al. (2002)

640 for data between 1997 and 2000, where on the basis of linear regression $\mathrm{Na}^{+}$has a dominant role on aerosol scattering in winter and $\mathrm{SO}_{4}{ }^{2-}$ in spring. Aerosol filter samples have been taken throughout the full period (1997-present), but data were not available beyond 2013 for this work. Future analysis will help answer the question whether an anthropogenic or natural source, or both, contribute to the observed decline. Conversely, at Zeppelin the overall summer and winter trends are positive for $\sigma_{s p}$, and strongly driven by changes in the decade between 2000 and 2010. The $S A E$ and $\sigma_{s p}$ trends have been discussed in detail by Heslin-Rees et al. (2020) who found that the increased scattering signal is likely due to an increased presence of coarse mode particles. This is reflected by the significant negative trend in the $S A E$ (also for both seasons). While it could be hypothesized that the retreat of sea ice is responsible, HeslinRees et al. (2020) found that a change in the atmospheric circulation, in which increased advection of air masses from the southwest, i.e. the Atlantic, can explain the observations. The conclusion is that more sea spray aerosol is transported towards Zeppelin contributing to the increased coarse mode particles. This is not confirmed by the derived trends of sea-salt particles with the same method $\left(\mathrm{Na}^{+}\right.$, see previous section). Here trends in $\mathrm{Na}^{+}$were not found to be significant for the Zeppelin station. However, the physico-chemical characterization of coarse-mode aerosols at Gruvebadet (Song et al., 2021; Udisti et al., 2016) showed the occurrence of several populations of anthropogenic, sea-salt and crustal particles exhibiting distinct coarse mode size-distributions, which complicates the attribution of trends in $S A E$ to individual changes in emissions

The absorption coefficient, which is mostly related to the presence of combustion related aerosol and, to a much lesser extent, to mineral dust, exhibits negative trends for the overall time periods of observations 660 at Barrow and Zeppelin in winter, consistent with the wintertime trends for absorption coefficient reported in Collaud Coen et al. (2020b). These trends are in line with the decreasing EBC concentrations during the haze season, where the EBC trend is significant at Zeppelin, while at Barrow the p-value is 0.09. 
Pallas shows a negative decadal trend for $S A E$ between 2000 and 2009 in summer. Thereafter variability has become larger between the years and the amplitude of the signal also increased. No particular reason has been found. In contrast, Collaud Coen et al. (2020b) observed both increasing and decreasing statistically significant $S A E$ trends at various Arctic sites depending on the time period and season considered.
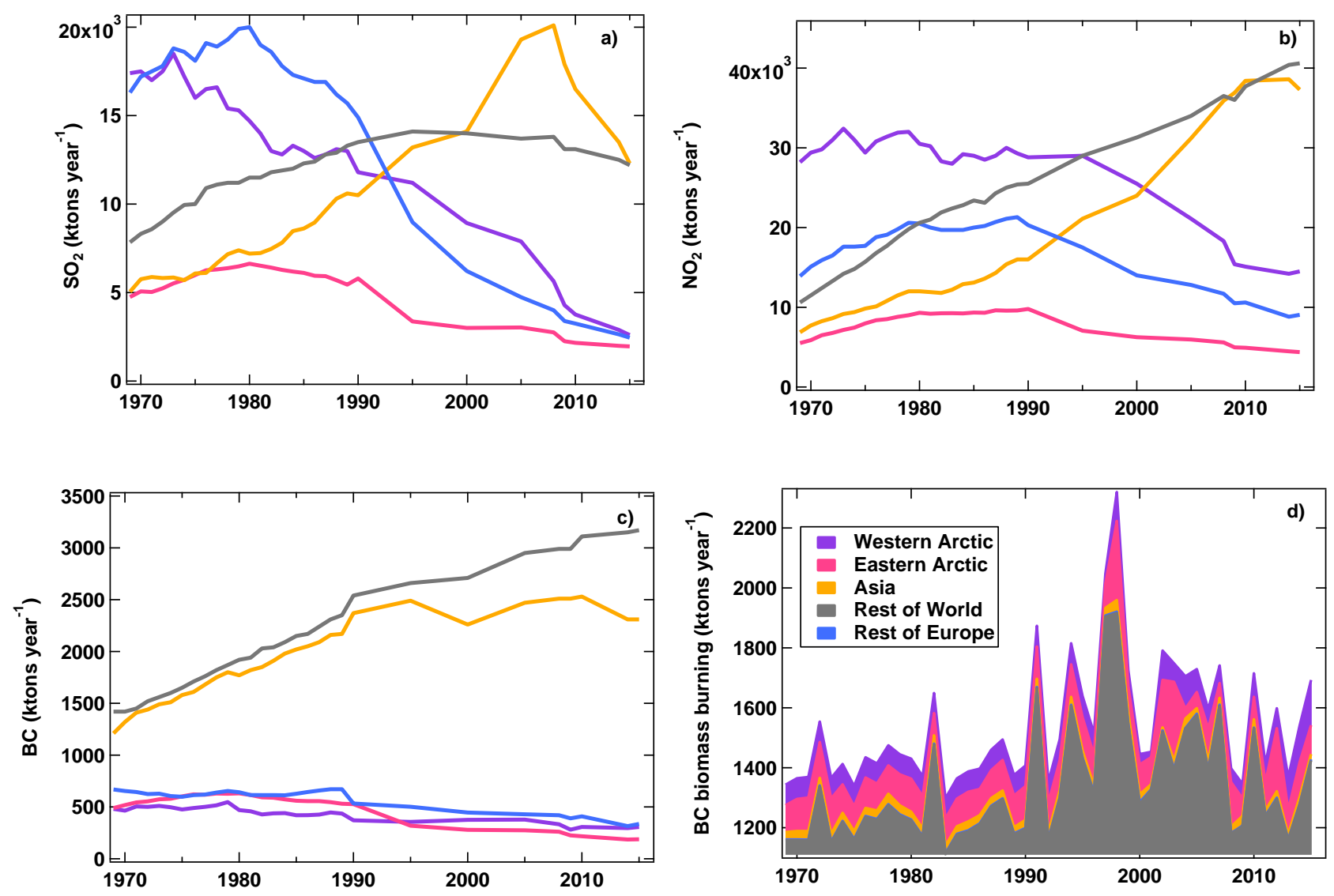

670 Figure 4: Anthropogenic emissions of $\mathrm{SO}_{2}$ (a), $\mathrm{NO}_{2}(\mathbf{b}), \mathrm{BC}(\mathrm{c})$, and $\mathrm{BC}$ from biomass burning (d). Anthropogenic emissions are based on ECLIPSE v6B (Höglund-Isaksson et al., 2020) . Data from before 1990 are based on CMIP6 (Hoesly et al., 2018; van Marle et al., 2017) scaled linearly to match ECLIPSE v6B. Biomass burning data are from CMIP6. The Western Arctic region refers to the following countries: USA and Canada; Eastern Arctic region: Kingdom of Denmark, Finland,

675 Iceland, Norway, the Russian Federation, and Sweden. The grouping follows the report of the Arctic Monitoring and Assessment Programme on short-lived climate forcers (AMAP, 2021). 


\section{Discussion}

The results presented above reflect the effort, which has been made to characterize the aerosol chemical

and optical properties across the Arctic over several decades, and they highlight the importance of this long-term effort. Importantly, to obtain a pan-Arctic view, records must be taken over the same period of time. Based on the data set behind this study, in the 1980s, on average, measurements of nine variables (chemical and optical) were carried out each year at any station considered here. In the 1990s the number increased to 23 , and further to 36 variables in the 2000s. In the latest decade, annual measurements of 39 variables were available on average. Note that not all data might have been released for the most recent years and hence the number is a lower estimate. We also limited the selection of aerosol variables measured to meet the objectives of the presented study (long-term trends).

The data allow us to draw conclusions on how changes in emissions, processes and transport in the northern hemisphere have changed the aerosol properties across the Arctic. Note that the applied methodology here, i.e. the Mann-Kendall significance test and Theil-Sen slope estimator, relies on monotonic change. Hence, time series which do not change monotonically are less likely to exhibit a significant trend (see e.g. the MSA concentration at Alert). We find in total 26 significant trends over full records, i.e. spanning more than a decade, compared to 17 significant decadal trends. The majority of significantly declining trends in anthropogenic tracers occurred during the haze period, and was driven by changes in the 1990. Even though the decade from 1990 to 1999 stands out, only four of the trends calculated for this decade are significant. This result means that long-term observations that cover multiple decades are extremely valuable and necessary to document the anthropogenic influence on the Arctic aerosol concentration. In addition, it can be concluded that observations which started after the 1990s cannot reflect the most important decline of the anthropogenic aerosol concentration in the Arctic in the recent past. Nevertheless, the more recently established monitoring activities will provide valuable insight into recent trends in the years to come with respect to anthropogenic emission changes within (Kolesar et al., 2017; Aliabadi et al., 2015; Schmale et al., 2018) and outside of the Arctic, as well as to potential changes in natural emissions based on climate feedback mechanisms. For example, we find from 
the recent records that EBC concentrations appear to be stagnating, i.e., no significant change is observed.

Because trends in the latest decade are not significant, continuing observations in the future is critical to understand the present-day development. The newly established time series at additional geographical locations will help evaluate this trend in the future; particularly in light of the current black carbon reduction policies, such as those initiated by the Arctic Council countries through the Fairbanks Declaration 2017 (Arctic Council, 2017), and whether those policies will have an effect across the Arctic. Anthropogenic influence has not been restricted to the haze season. Two significant negative trends in summer for EBC and Fe seem to demonstrate this, because there are corresponding negative trends during the haze period as well. With the decline of anthropogenic air pollution, natural aerosol components emerge more strongly now in summer than previously and are hence responsible for the larger part of the summertime aerosol climate effects, including both the direct and indirect effects. The vanishing 715 anthropogenic summer influence coincides with rapid and unprecedented environmental change in the high northern latitudes. September Arctic sea ice is retreating by $13.1 \%$ per decade since 1979 compared to the 1981-2010 average (Arctic Sea Ice Minimum, 2020). Sea ice retreat creates more open ocean, which creates larger fetch for wave development (Casas-Prat and Wang, 2020) and hence more sea spray emission. DMS emissions have increased by 33 \% per decade in ice-free water since 1998 (Galí et al., 720 2019). Boreal forest fires are also becoming more frequent and severe (Rogers et al., 2020). For example, BC emissions have roughly doubled from 2010 to 2020 from wildfires north of $60^{\circ} \mathrm{N}$ (McCarty et al., 2021). Warmer temperatures, which are the main cause of enhanced fire activity, also cause enhanced biogenic emissions, such as isoprene (a secondary organic aerosol precursor originating from vegetation (Arneth et al., 2016)). These and other ongoing and anticipated environmental changes (e.g., changed wind and air mass transport patterns) will have an effect on the natural contribution to aerosol properties and concentrations (Schmale et al., 2021). However, the trend analyses of natural aerosol tracers used in this study do not show strong or unambiguous evidence for such changes yet. There can be several reasons. With respect to $\mathrm{SO}_{4}{ }^{2-}$, there could be compensating effects of reduced $\mathrm{SO}_{2}$ emissions and increased DMS emissions. For example, a high interannual variability in natural sources hinders the detection of long-term trends. Additionally the complex relationships between natural emissions, atmospheric transport, chemical reactions, particle removal processes and observed airborne aerosol 
concentrations, means that an increase in emissions does not automatically translate to enhanced concentrations of corresponding end products or the species itself. Furthermore, our analyses are conducted with the Mann-Kendall Theil-Sen Slope test only. Other methods might yield different results.

735 For example, increased wave breaking on a more ice-free ocean should lead to higher $\mathrm{Na}^{+}$concentrations. However, none of the four stations that report $\mathrm{Na}^{+}$show a significant trend. This could be due to the inherently large variability in the $\mathrm{Na}^{+}$signal, which requires hence longer data sets to extract a monotonic signal with the Mann-Kendall Theil-Sen methodology. For Alert, if the $\mathrm{Na}^{+}$concentration for the first five years of the record and the last five years are averaged, there is a $20 \%$ increase in $\mathrm{Na}^{+}$. It could also

740 be due to the preferential wet scavenging of $\mathrm{Na}^{+}$due to its high hygroscopicity. In addition to the chemical signature, which can document changes in sea spray aerosol, size distribution data can provide indications and improve such analysis. Using the $S A E$, Heslin-Rees et al. (2020) showed an increase in coarse mode particles at Zeppelin, which is likely due to an increase of observations in sea spray emissions and atmospheric transport changes. At Zeppelin, the source is the mid-latitude Atlantic rather than the increasingly ice-free Arctic Ocean. While at Alert, the SAE trend was not found to be significant, it nevertheless has a low p-value of 0.09 and a negative slope, which is consistent with the decrease in $\mathrm{Na}^{+}$. Concerning marine biogenic emissions, observations of MSA concentrations provide mixed results. While at Barrow the MSA time series from 1997 to 2017 shows an increase (Moffett et al., 2020), measurements at Alert do not indicate a significant upward trend between 1981 and 2018, but rather a negative trend between 1981 and 1999, and a positive trend in the decade 2000 to 2009 in MSA. Becagli et al. (2019) find a positive trend in the most recent decade at Gruvebadet on Svalbard and a negative one at Thule, Greenland. Our analyses in this study show similar trends for the two latter stations, but no significance. In a modeling study (Browse et al., 2014) found that enhanced marine biogenic emissions do contribute to enhanced aerosol concentrations, but they also cause increased wet deposition, such that higher concentrations of marine biogenic tracers might not be measured at the observatories.

Regarding the potential increase in biomass burning aerosol, there is no observatory indicating a significant positive trend in relevant components (e.g., EBC, absorption coefficient, nssK ${ }^{+}$). The absence of trends might be due to atmospheric transport patterns, meaning observatories might not be located in the regions that are consistently influenced by enhanced biomass burning. Importantly, biomass burning 
emissions are also ejected higher aloft into the atmosphere, meaning surface stations might not capture these layers due to down-limited mixing in the stratified polar atmosphere. It could also partly be owing to the lack of observations of more specific tracers for biomass burning.

Less snow cover in summer might lead to the hypothesis that enhanced local soil dust emissions can contribute to the aerosol burden at Arctic sites. While soil dust tracer data were available for four stations, none of them showed a significant increase for the overall period, neither during winter nor summer. In contrast, summer nssCa ${ }^{2+}$ declined at Alert, indicating that potentially long-range transport is the more important factor at this station.

The current absence of significant trends in natural aerosol components might be a result of the choice of aerosol tracers measured at the observatories. While MSA is a unique tracer for marine biogenic emissions, and the $\mathrm{Na}^{+}$signal is governed by sea salt (Udisti et al., 2016), there is a lack of unique tracers for dust and terrestrial biogenic emissions. Those need to be identified using statistical tools or models. For the latter, observations and speciation of organic aerosol with spatial coverage in the Arctic, and in particular secondary organic aerosol, is desperately needed for better source apportionment (Petäjä et al., 2020; Frossard et al., 2011). Analyses based on short-term efforts clearly show the potential of various analyses techniques (mass spectrometry or Fourier transform infrared spectral analysis) to isolate signatures of anthropogenic versus natural organic aerosol contribution (Fu et al., 2009; Kawamura et al., 2010; Leaitch et al., 2018; Willis et al., 2017). Isotopic analyses of carbon, nitrogen and sulfur can also provide more details on sources. This has been demonstrated by carbon isotope analyses on atmospheric and deposited aerosols (Rodríguez et al., 2020; Winiger et al., 2019). Nitrogen isotopic analysis has been used to elucidate the $\mathrm{NO}_{\mathrm{x}}$ budget in the Arctic, however the study was more focused (Dall'Osto et al., 2018; Schmale and Baccarini, 2021) on trace gas chemistry rather than aerosol source apportionment (Morin et al., 2008). Sulfur isotopic analysis has been applied a limited number of times for shorter term data sets in the Arctic to distinguish anthropogenic, biogenic and sea salt contributions (Ghahremaninezhad et al., 2016; Seguin et al., 2014). This can also be achieved by online mass 785 spectrometry as has been done at Villum (Nielsen et al., 2019). Also, microphysical properties such as particle size distributions can reveal changes that bulk aerosol composition cannot. For example, chemical analyses are mostly mass based, and hence changes in particles with smaller diameters are not well 
captured by such analysis. Those however have already been shown to reflect enhanced contribution of marine biogenic emissions to new particle formation and growth (Dall'Osto et al., 2017; Beck et al., 2020). In addition, optical properties can reflect changes in particle size distributions, for example the SAE at Zeppelin, where the aerosol population seems to evolve in a way that larger particles dominate. While this is attributed to more frequent observations of sea spray from the Atlantic (Heslin-Rees et al., 2020), the chemical measurements of $\mathrm{Na}^{+}$at Zeppelin did not capture this change at the $95^{\text {th }} \%$ significance level. However, a combination of chemical and optical measurements can shed more light on particle origin and driving factors of climate-relevant optical aerosol properties (Quinn et al., 2002). Despite the large data set discussed here, the chemical and optical observations only coincide marginally. Hence, long-term trends of their co-evolution are not investigated, but such a study would provide very useful insights, particularly adding detailed size distribution information.

\section{Conclusions and outlook}

800 We presented and analyzed more than a cumulative 1000 years of measurements of aerosol chemical and optical properties recorded at ten surface observatories across the Arctic between 1967 and 2019. Variables include $\mathrm{EBC}, \mathrm{SO}_{4}{ }^{2+}, \mathrm{NO}_{3}{ }^{-}, \mathrm{NH}^{+}, \mathrm{MSA}, \mathrm{Na}^{+}, \mathrm{nssCa}^{2+}, \mathrm{nssK}^{+}, \mathrm{Fe}$, scattering and absorption coefficients, SSA and SAE (Table 2).

Annual cycles of all variables clearly show that the wintertime is still dominated by anthropogenic haze

across the whole Arctic, while the summer is more strongly influenced by natural aerosol components. Significantly decreasing long-term trends of anthropogenic tracers provide evidence of the decline of human emissions further south which is observed during the haze season at Arctic sites. The strongest decline in $\mathrm{SO}_{2}$ and $\mathrm{BC}$ emissions took place in the 1990s and is visible in large decreases of particulate sulfate and EBC in the North American and European Arctic. Available data from the Eastern Arctic covers only the most recent decades and hence could not capture the change. In the recent past, EBC concentrations seemed to stagnate or slightly increase (not significantly). We calculated that concentration increases of at least $5 \%$ per year are currently needed to detect a significant trend per decade, due to the interannual variability of EBC concentrations. Lower rates of change are detectable 
only over longer periods of time. Future data will show, whether recent efforts by the Arctic Council members in reducing emissions, particularly of black carbon, are effective (Arctic Council, 2017). Among all long-term trends, $29 \%$ are significant in the haze season where 13 out of 16 show a decline. The two positive trends include $\mathrm{NO}_{3}{ }^{-}$at Alert and scattering coefficient at Zeppelin. Despite $\mathrm{NO}_{\mathrm{x}}$ emissions decrease at mid-latitudes, particulate nitrate might increase at Alert due to atmospheric chemical processes favoring nitrate partitioning into particles due to the less acidic aerosol (less sulfate). At Zeppelin the enhanced scattering coefficient comes along with a decrease in the $S A E$, indicating a stronger contribution of larger particles, i.e. sea spray from the mid-latitude Atlantic (Heslin-Rees et al., 2020).

For the summer period, no uniform picture of trends has emerged. Twenty-one percent of trends, i.e. eleven out of 57, are significant, whereby five are positive and six are negative. Negative trends include not only anthropogenic tracers such as EBC at Kevo, but also natural indicators such as MSA and nssCa ${ }^{2+}$ at Alert. Positive trends are observed for $\mathrm{SO}_{4}{ }^{2+}$ at Zeppelin and Gruvebadet. Those could be related to enhanced marine biogenic emissions, but analogous significant trends in MSA were not found. Hence, no clear evidence of a significant change in the natural aerosol contribution can be seen yet, despite the evident sea ice decline, increased DMS, and increased fire and terrestrial vegetation emissions (Arneth et al., 2016; Galí et al., 2019; Arctic Sea Ice Minimum, 2020; Rogers et al., 2020). This points towards four main action items for monitoring Arctic aerosol.

- First, long-term observations targeted at natural aerosol tracers are needed. Increased natural particle and precursor emissions might produce signal enhancements, which are small compared to the inherent signal variability. Hence, new trends might not yet be visible but might emerge in the years to come. They are important indicators of feedback mechanisms in Arctic amplification.

- Second, the location of an observatory matters for which trends might emerge as significant or not. Not every observatory will exhibit all types of natural aerosol changes clearly. For example, Becagli et al. (2019) find a difference in MSA trends between Gruvebadet and Thule, likely due to different evolution of marine ecosystems. A natural change hot spot map of the Arctic combined with simulations of atmospheric transport and aerosol processes can suggest areas that require 
new measurement efforts. Moreover, most stations are located near sea level, and only Summit provides valuable insights into processes further aloft including in the free troposphere.

- Third, an assessment of whether the currently monitored aerosol properties are appropriate to capture changes in natural aerosol compounds is needed. Source apportionment based on speciated organic aerosol components is currently lacking except for a few short-term case studies (Petäjä et al., 2020; Frossard et al., 2011). Those together with isotopic analyses of carbon, nitrogen and sulfur can shed light into natural aerosol changes. Microphysical properties such as the size distribution and inherent optical characteristics such as the single scattering albedo and scattering Ångström exponent can further reveal changes in the number, size and composition and thus origin of particles, which chemical analyses alone, especially of bulk aerosols, cannot.

- Fourth, standard operation procedures for the measurement of particle properties are needed such that they can be compared (e.g. same cut-off size on the inlets).

In summary, aerosol properties are an important tool to analyze changes in anthropogenic and natural atmospheric chemical influences on the Arctic. Tremendous monitoring efforts have already been conducted, which have helped to understand the implications for past, present and future Arctic climate change. The decision to start regular monitoring of key anthropogenic components in the early 1990's or even before - turned out to be important and timely, because it enabled us to capture a remarkable change in the concentrations of anthropogenic climate-forcing agents in the Arctic lower atmosphere that occurred in the late twentieth century. Establishing specifically targeted observations for the ongoing and future change of natural aerosols are essential to develop improved scenarios of their climatic and biogeochemical effects on the Arctic. Continuation of the monitoring programs targeting changes in variables during the haze season linked to anthropogenic emissions at mid-latitudes is a prerequisite to give further evidence to the declining trends determined today and for their quantification feeding global climate and earth system models. 


\section{Acknowledgements}

We thank the entire Arctic Monitoring and Assessment Programme Expert Group on Short-lived Climate

870 Forcers for inspiring conversations and feedback. For Alert, authors would like to thank operators, students and technicians for the aerosol program operations, calibrations and maintenance of instruments, especially Dan Veber for maintenance of optical and physical measurements instruments and Alina Chivulescu for aerosol sample chemical analysis. CFS Alert for maintenance of Alert base station. The Villum Foundation is gratefully acknowledged for financing the establishment of the Villum Research

875 Station. Thanks to the Royal Danish Air Force and the Arctic Command for providing logistic support to the project. The data from Gruvebadet were achieved thanks to Projects PRIN- 20092C7KRC001 and RIS 3693 "Gruvebadet Atmospheric Laboratory Project (GRUVELAB)" and to the coordination activity of National Council of Research (CNR), which manages the Italian Arctic Station "Dirigibile Italia" through the Institute of Polar Sciences (ISP). For Barrow, PMEL would like to thank all of the station operators who have made sample collection possible over the past years. This is PMEL contribution number 5287. For Barrow, Summit and Tiksi the authors would like to thank the operators for the care and feeding of chemical and optical instruments and Derek Hageman for his continued excellence in data acquisition, processing and archiving of data.

\section{Financial support.}

This work received support from the Swiss National Science Foundation (grant no. 200021_188478). J.S. holds the Ingvar Kamprad Chair for Extreme Environments Research sponsored by Ferring Pharmaceuticals. This research has been financially supported by the Danish Environmental Protection Agency and the Danish Energy Agency, with means from MIKA/DANCEA funds for environmental support to the Arctic region (project nos. Danish EPA: MST-113-00-140; Ministry of Climate, Energy, and Utilities: 2018-3767) and ERA-PLANET (The European Network for observing our changing Planet) projects, as well as by iGOSP, iCUPE. Measurements and data evaluation for aerosol optical properties at Barrow are supported by DOE/ARM (ANL award\# 0F-60239), measurements at Summit occur under 
the aegis of NSF and NOAA, and aethalometer measurements at Tiksi occurred through NOAA cooperation with Roshydromet that ended in 2018.

\section{Data availability}

Most data are publicly available on ebas.nilu.no or else on request via the personal communication contacts listed in Table 1. All these contacts are co-authors and in charge of observatory data, which needs 900 to undergo specific control before it can be posted publicly. This publication partly precedes open access data publication. All data will be available via ebas.nilu.no in the future.

\section{Author contributions}

LU, PKQ, EA, AM, JBP, SS, SD, KE processed and analyzed data from the observatories. JS, SS, and 905 SD calculated annual cycles and seasonal trends. KVS provided emissions data. JS wrote the manuscript. All authors contributed to interpretation and commented on the manuscript. 


\section{References}

Aaltonen, V., Lihavainen, H., Kerminen, V.-M., Komppula, M., Hatakka, J., Eneroth, K., Kulmala, M., and Viisanen, Y.: Measurements of optical properties of atmospheric aerosols in Northern Finland, Atmos. Chem. Phys., 6, 1155-1164, https://doi.org/10.5194/acp-6-1155-2006, 2006.

915 Aliabadi, A. A., Staebler, R. M., and Sharma, S.: Air quality monitoring in communities of the Canadian Arctic during the high shipping season with a focus on local and marine pollution, 15, 2651-2673, https://doi.org/10.5194/acp-15-2651-2015, 2015 .

AMAP: AMAP Assessment 2006: Acidifying Pollutants, Arctic Haze, and Acidification in the Arctic, Arctic Monitoring and Assessment Programme (AMAP), Oslo, Norway, 2006.

AMAP: The Impact of Black Carbon on the Arctic Climate, Arctic Monitoring and Assessment Programme, Oslo, 2011.

AMAP: AMAP Assessment 2015: Black carbon and ozone as Arctic climate forcers, Arctic Monitoring and Assessment Programme (AMAP), Oslo, Norway, 2015.

AMAP: AMAP, 2021, forthcoming, 2021.

Arctic Council: Fairbanks Declaration (2017), Arctic Council, Fairbanks, 2017.

925 Arneth, A., Makkonen, R., Olin, S., Paasonen, P., Holst, T., Kajos, M. K., Kulmala, M., Maximov, T., Miller, P. A., and Schurgers, G.: Future vegetation-climate interactions in Eastern Siberia: an assessment of the competing effects of $\mathrm{CO} 2$ and secondary organic aerosols, Atmos. Chem. Phys., 16, 5243-5262, https://doi.org/10.5194/acp-16-5243-2016, 2016.

Arrigo, K. R., Perovich, D. K., Pickart, R. S., Brown, Z. W., van Dijken, G. L., Lowry, K. E., Mills, M. M., Palmer, M. A., Balch, W. M., Bahr, F., Bates, N. R., Benitez-Nelson, C., Bowler, B., Brownlee, E., Ehn, J. K., Frey, K. E., Garley, R., Laney,

930 S. R., Lubelczyk, L., Mathis, J., Matsuoka, A., Mitchell, B. G., Moore, G. W. K., Ortega-Retuerta, E., Pal, S., Polashenski, C. M., Reynolds, R. A., Schieber, B., Sosik, H. M., Stephens, M., and Swift, J. H.: Massive Phytoplankton Blooms Under Arctic Sea Ice, 336, 1408-1408, https://doi.org/10.1126/science.1215065, 2012.

Asmi, E., Kondratyev, V., Brus, D., Laurila, T., Lihavainen, H., Backman, J., Vakkari, V., Aurela, M., Hatakka, J., Viisanen, Y., Uttal, T., Ivakhov, V., and Makshtas, A.: Aerosol size distribution seasonal characteristics measured in Tiksi, Russian 935 Arctic, 16, 1271-1287, https://doi.org/10.5194/acp-16-1271-2016, 2016.

Baccarini, A., Karlsson, L., Dommen, J., Duplessis, P., Vüllers, J., Brooks, I. M., Saiz-Lopez, A., Salter, M., Tjernström, M., Baltensperger, U., Zieger, P., and Schmale, J.: Frequent new particle formation over the high Arctic pack ice by enhanced iodine emissions, Nature Communications, 11, 4924, https://doi.org/10.1038/s41467-020-18551-0, 2020.

Backman, J., Schmeisser, L., Virkkula, A., Ogren, J. A., Asmi, E., Starkweather, S., Sharma, S., Eleftheriadis, K., Uttal, T.,

940 Jefferson, A., Bergin, M., Makshtas, A., Tunved, P., and Fiebig, M.: On Aethalometer measurement uncertainties and an instrument correction factor for the Arctic, 10, 5039-5062, https://doi.org/10.5194/amt-10-5039-2017, 2017.

Backman, J., Schmeisser, L., and Asmi, E.: Asian Emissions Explain Much of the Arctic Black Carbon Events, Geophysical Research Letters, 48, e2020GL091913, https://doi.org/10.1029/2020GL091913, 2021. 
Barrie, L. A.: Arctic air pollution: An overview of current knowledge, 20, 643-663, https://doi.org/10.1016/00046981(86)90180-0, 1986.

Becagli, S., Lazzara, L., Marchese, C., Dayan, U., Ascanius, S. E., Cacciani, M., Caiazzo, L., Di Biagio, C., Di Iorio, T., di Sarra, A., Eriksen, P., Fani, F., Giardi, F., Meloni, D., Muscari, G., Pace, G., Severi, M., Traversi, R., and Udisti, R.: Relationships linking primary production, sea ice melting, and biogenic aerosol in the Arctic, Atmospheric Environment, 136, 1-15, https://doi.org/10.1016/j.atmosenv.2016.04.002, 2016.

950 Becagli, S., Amore, A., Caiazzo, L., Iorio, T. D., Sarra, A. D., Lazzara, L., Marchese, C., Meloni, D., Mori, G., Muscari, G., Nuccio, C., Pace, G., Severi, M., and Traversi, R.: Biogenic Aerosol in the Arctic from Eight Years of MSA Data from Ny Ålesund (Svalbard Islands) and Thule (Greenland), Atmosphere, 10, 349, https://doi.org/10.3390/atmos10070349, 2019.

Beck, L. J., Sarnela, N., Junninen, H., Hoppe, C. J. M., Garmash, O., Bianchi, F., Riva, M., Rose, C., Peräkylä, O., Wimmer, D., Kausiala, O., Jokinen, T., Ahonen, L., Mikkilä, J., Hakala, J., He, X.-C., Kontkanen, J., Wolf, K. K. E., Cappelletti, D., Mazzola, M., Traversi, R., Petroselli, C., Viola, A. P., Vitale, V., Lange, R., Massling, A., Nøjgaard, J. K., Krejci, R., Karlsson, L., Zieger, P., Jang, S., Lee, K., Vakkari, V., Lampilahti, J., Thakur, R. C., Leino, K., Kangasluoma, J., Duplissy, E.-M., Siivola, E., Marbouti, M., Tham, Y. J., Saiz-Lopez, A., Petäjä, T., Ehn, M., Worsnop, D. R., Skov, H., Kulmala, M., Kerminen, V.-M., and Sipilä, M.: Differing mechanisms of new particle formation at two Arctic sites., Geophysical Research Letters, n/a, e2020GL091334, https://doi.org/10.1029/2020GL091334, 2020.

960 Bodhaine, B. A. and Dutton, E. G.: A long-term decrease in Arctic haze at Barrow, Alaska, Geophysical Research Letters, 20, 947-950, https://doi.org/10.1029/93GL01146, 1993.

Browse, J., Carslaw, K. S., Mann, G. W., Birch, C. E., Arnold, S. R., and Leck, C.: The complex response of Arctic aerosol to sea-ice retreat, 14, 7543-7557, https://doi.org/10.5194/acp-14-7543-2014, 2014.

Casas-Prat, M. and Wang, X. L.: Sea Ice Retreat Contributes to Projected Increases in Extreme Arctic Ocean Surface Waves,

Geophysical Research Letters, 47, e2020GL088100, https://doi.org/10.1029/2020GL088100, 2020.

Collaud Coen, M., Andrews, E., Bigi, A., Martucci, G., Romanens, G., Vogt, F. P. A., and Vuilleumier, L.: Effects of the prewhitening method, the time granularity, and the time segmentation on the Mann-Kendall trend detection and the associated Sen's slope, Atmos. Meas. Tech., 13, 6945-6964, https://doi.org/10.5194/amt-13-6945-2020, 2020a.

Collaud Coen, M., Andrews, E., Alastuey, A., Arsov, T. P., Backman, J., Brem, B. T., Bukowiecki, N., Couret, C., 970 Eleftheriadis, K., Flentje, H., Fiebig, M., Gysel-Beer, M., Hand, J. L., Hoffer, A., Hooda, R., Hueglin, C., Joubert, W., Keywood, M., Kim, J. E., Kim, S.-W., Labuschagne, C., Lin, N.-H., Lin, Y., Lund Myhre, C., Luoma, K., Lyamani, H., Marinoni, A., Mayol-Bracero, O. L., Mihalopoulos, N., Pandolfi, M., Prats, N., Prenni, A. J., Putaud, J.-P., Ries, L., Reisen, F., Sellegri, K., Sharma, S., Sheridan, P., Sherman, J. P., Sun, J., Titos, G., Torres, E., Tuch, T., Weller, R., Wiedensohler, A., Zieger, P., and Laj, P.: Multidecadal trend analysis of in situ aerosol radiative properties around the world, Atmos. Chem.

975 Phys., 20, 8867-8908, https://doi.org/10.5194/acp-20-8867-2020, 2020 b.

Croft, B., Martin, R. V., Leaitch, W. R., Tunved, P., Breider, T. J., D’Andrea, S. D., and Pierce, J. R.: Processes controlling the annual cycle of Arctic aerosol number and size distributions, 16, 3665-3682, https://doi.org/10.5194/acp-16-3665-2016, 2016.

Dall’Osto, M., Beddows, D. C. S., Tunved, P., Krejci, R., Ström, J., Hansson, H. C., Yoon, Y. J., Park, K.-T., Becagli, S., 980 Udisti, R., Onasch, T., O’Dowd, C. D., Simó, R., and Harrison, R. M.: Arctic sea ice melt leads to atmospheric new particle formation, 7, 3318, https://doi.org/10.1038/s41598-017-03328-1, 2017. 
https://doi.org/10.5194/acp-2021-756

Preprint. Discussion started: 8 September 2021

(c) Author(s) 2021. CC BY 4.0 License.

Atmospheric

Chemistry

(c) (i)

and Physics

Discussions

Dall’Osto, M., Geels, C., Beddows, D. C. S., Boertmann, D., Lange, R., Nøjgaard, J. K., Harrison, R. M., Simo, R., Skov, H., and Massling, A.: Regions of open water and melting sea ice drive new particle formation in North East Greenland, 8, 6109, https://doi.org/10.1038/s41598-018-24426-8, 2018.

985 Delene, D. J. and Ogren, J. A.: Variability of Aerosol Optical Properties at Four North American Surface Monitoring Sites, 59, 1135-1150, https://doi.org/10.1175/1520-0469(2002)059<1135:VOAOPA>2.0.CO;2, 2002.

Dutkiewicz, V. A., DeJulio, A. M., Ahmed, T., Laing, J., Hopke, P. K., Skeie, R. B., Viisanen, Y., Paatero, J., and Husain, L.: Forty-seven years of weekly atmospheric black carbon measurements in the Finnish Arctic: Decrease in black carbon with declining emissions, 119, 7667-7683, https://doi.org/10.1002/2014JD021790, 2014.

990 Eckhardt, S., Hermansen, O., Grythe, H., Fiebig, M., Stebel, K., Cassiani, M., Baecklund, A., and Stohl, A.: The influence of cruise ship emissions on air pollution in Svalbard - a harbinger of a more polluted Arctic?, 13, 8401-8409, https://doi.org/10.5194/acp-13-8401-2013, 2013.

Eckhardt, S., Quennehen, B., Olivié, D. J. L., Berntsen, T. K., Cherian, R., Christensen, J. H., Collins, W., Crepinsek, S., Daskalakis, N., Flanner, M., Herber, A., Heyes, C., Hodnebrog, Ø., Huang, L., Kanakidou, M., Klimont, Z., Langner, J., Law,

995 K. S., Lund, M. T., Mahmood, R., Massling, A., Myriokefalitakis, S., Nielsen, I. E., Nøjgaard, J. K., Quaas, J., Quinn, P. K., Raut, J. C., Rumbold, S. T., Schulz, M., Sharma, S., Skeie, R. B., Skov, H., Uttal, T., von Salzen, K., and Stohl, A.: Current model capabilities for simulating black carbon and sulfate concentrations in the Arctic atmosphere: a multi-model evaluation using a comprehensive measurement data set, 15, 9413-9433, https://doi.org/10.5194/acp-15-9413-2015, 2015.

Eleftheriadis, K., Vratolis, S., and Nyeki, S.: Aerosol black carbon in the European Arctic: Measurements at Zeppelin station, Ny-Ålesund, Svalbard from 1998-2007, Geophysical Research Letters, 36, https://doi.org/10.1029/2008GL035741, 2009.

Fenger, M., Sørensen, L. L., Kristensen, K., Jensen, B., Nguyen, Q. T., Nøjgaard, J. K., Massling, A., Skov, H., Becker, T., and Glasius, M.: Sources of anions in aerosols in northeast Greenland during late winter, 13, 1569-1578, https://doi.org/10.5194/acp-13-1569-2013, 2013.

Flannigan, M., STOCKS, B., TURETSKY, M., and WOTTON, M.: Impacts of climate change on fire activity and fire management in the circumboreal forest, Global Change Biology, 15, 549-560, https://doi.org/10.1111/j.13652486.2008.01660.x, 2009.

Freud, E., Krejci, R., Tunved, P., Leaitch, R., Nguyen, Q. T., Massling, A., Skov, H., and Barrie, L.: Pan-Arctic aerosol number size distributions: seasonality and transport patterns, 17, 8101-8128, https://doi.org/10.5194/acp-17-8101-2017, 2017.

Frossard, A. A., Shaw, P. M., Russell, L. M., Kroll, J. H., Canagaratna, M. R., Worsnop, D. R., Quinn, P. K., and Bates, T. S.:

1010 Springtime Arctic haze contributions of submicron organic particles from European and Asian combustion sources, Journal of Geophysical Research: Atmospheres, 116, https://doi.org/10.1029/2010JD015178, 2011.

Fu, P. Q., Kawamura, K., Chen, J., and Barrie, L. A.: Isoprene, Monoterpene, and Sesquiterpene Oxidation Products in the High Arctic Aerosols during Late Winter to Early Summer, Environ. Sci. Technol., 43, 4022-4028, https://doi.org/10.1021/es803669a, 2009.

1015 Galí, M., Devred, E., Babin, M., and Levasseur, M.: Decadal increase in Arctic dimethylsulfide emission, 116, 19311-19317, https://doi.org/10.1073/pnas.1904378116, 2019.

Ghahremaninezhad, R., Norman, A.-L., Abbatt, J. P. D., Levasseur, M., and Thomas, J. L.: Biogenic, anthropogenic and sea salt sulfate size-segregated aerosols in the Arctic summer, Atmos. Chem. Phys., 16, 5191-5202, https://doi.org/10.5194/acp16-5191-2016, 2016. 
1020 Gilardoni, S.: Atmospheric black carbon in Svalbard (ABC Svalbard), SIOS, Svalbard, 2019.

Groot Zwaaftink, C. D., Grythe, H., Skov, H., and Stohl, A.: Substantial contribution of northern high-latitude sources to mineral dust in the Arctic, 121, 13,678-13,697, https://doi.org/10.1002/2016JD025482, 2016.

Gunsch, M. J., Kirpes, R. M., Kolesar, K. R., Barrett, T. E., China, S., Sheesley, R. J., Laskin, A., Wiedensohler, A., Tuch, T., and Pratt, K. A.: Contributions of transported Prudhoe Bay oil field emissions to the aerosol population in Utqiagvik, Alaska, 17, 10879-10892, https://doi.org/10.5194/acp-17-10879-2017, 2017.

Guo, H., Sullivan, A. P., Campuzano-Jost, P., Schroder, J. C., Lopez-Hilfiker, F. D., Dibb, J. E., Jimenez, J. L., Thornton, J. A., Brown, S. S., Nenes, A., and Weber, R. J.: Fine particle $\mathrm{pH}$ and the partitioning of nitric acid during winter in the northeastern United States, Journal of Geophysical Research: Atmospheres, 121, 10,355-10,376, https://doi.org/10.1002/2016JD025311, 2016.

1030 Heidam, N. Z.: On the origin of the arctic aerosol: A statistical approach, Atmospheric Environment (1967), 15, 1421-1427, https://doi.org/10.1016/0004-6981(81)90348-6, 1981.

Heidam, N. Z., Wåhlin, P., and Christensen, J. H.: Tropospheric Gases and Aerosols in Northeast Greenland, 56, 261-278, https://doi.org/10.1175/1520-0469(1999)056<0261:TGAAIN>2.0.CO;2, 1999.

Heidam, N. Z., Christensen, J., Wåhlin, P., and Skov, H.: Arctic atmospheric contaminants in NE Greenland: levels, variations, origins, transport, transformations and trends 1990-2001, Science of The Total Environment, 331, 5-28, https://doi.org/10.1016/j.scitotenv.2004.03.033, 2004.

Heslin-Rees, D., Burgos, M., Hansson, H.-C., Krejci, R., Ström, J., Tunved, P., and Zieger, P.: From a polar to a marine environment: has the changing Arctic led to a shift in aerosol light scattering properties?, Atmos. Chem. Phys., 20, 1367113686, https://doi.org/10.5194/acp-20-13671-2020, 2020.

1040 Hirdman, D., Burkhart, J. F., Sodemann, H., Eckhardt, S., Jefferson, A., Quinn, P. K., Sharma, S., Ström, J., and Stohl, A.: Long-term trends of black carbon and sulphate aerosol in the Arctic: changes in atmospheric transport and source region emissions, Atmos. Chem. Phys., 10, 9351-9368, https://doi.org/10.5194/acp-10-9351-2010, 2010a.

Hirdman, D., Sodemann, H., Eckhardt, S., Burkhart, J. F., Jefferson, A., Mefford, T., Quinn, P. K., Sharma, S., Strom, J., and Stohl, A.: Source identification of short-lived air pollutants in the Arctic using statistical analysis of measurement data and particle dispersion model output, 10, 669-693, 2010b.

Hirsch, R. M., Slack, J. R., and Smith, R. A.: Techniques of trend analysis for monthly water quality data, Water Resources Research, 18, 107-121, https://doi.org/10.1029/WR018i001p00107, 1982.

Hodshire, A. L., Campuzano-Jost, P., Kodros, J. K., Croft, B., Nault, B. A., Schroder, J. C., Jimenez, J. L., and Pierce, J. R.: The potential role of methanesulfonic acid (MSA) in aerosol formation and growth and the associated radiative forcings, Atmos. Chem. Phys., 19, 3137-3160, https://doi.org/10.5194/acp-19-3137-2019, 2019.

Hoesly, R. M., Smith, S. J., Feng, L., Klimont, Z., Janssens-Maenhout, G., Pitkanen, T., Seibert, J. J., Vu, L., Andres, R. J., Bolt, R. M., Bond, T. C., Dawidowski, L., Kholod, N., Kurokawa, J. I., Li, M., Liu, L., Lu, Z., Moura, M. C. P., O'Rourke, P. R., and Zhang, Q.: Historical (1750-2014) anthropogenic emissions of reactive gases and aerosols from the Community Emissions Data System (CEDS), 11, 369-408, https://doi.org/10.5194/gmd-11-369-2018, 2018. 
1055 Hoffmann, E. H., Tilgner, A., Schrödner, R., Bräuer, P., Wolke, R., and Herrmann, H.: An advanced modeling study on the impacts and atmospheric implications of multiphase dimethyl sulfide chemistry, Proc Natl Acad Sci USA, 113, 11776, https://doi.org/10.1073/pnas.1606320113, 2016.

Höglund-Isaksson, L., Gómez-Sanabria, A., Klimont, Z., Rafaj, P., and Schöpp, W.: Technical potentials and costs for reducing global anthropogenic methane emissions in the 2050 timeframe -results from the GAINS model, 2, 025004, https://doi.org/10.1088/2515-7620/ab7457, 2020.

Huang, J. and Jaeglé, L.: Wintertime enhancements of sea salt aerosol in polar regions consistent with a sea ice source from blowing snow, 17, 3699-3712, https://doi.org/10.5194/acp-17-3699-2017, 2017.

Kawamura, K., Kasukabe, H., and Barrie, L. A.: Secondary formation of water-soluble organic acids and alpha-dicarbonyls and their contributions to total carbon and water-soluble organic carbon: Photochemical aging of organic aerosols in the Arctic spring, J. Geophys. Res.-Atmos., 115, 17, https://doi.org/10.1029/2010jd014299, 2010.

Kirpes, R. M., Bondy, A. L., Bonanno, D., Moffet, R. C., Wang, B., Laskin, A., Ault, A. P., and Pratt, K. A.: Secondary sulfate is internally mixed with sea spray aerosol and organic aerosol in the winter Arctic, 18, 3937-3949, https://doi.org/10.5194/acp18-3937-2018, 2018.

Kolesar, K. R., Cellini, J., Peterson, P. K., Jefferson, A., Tuch, T., Birmili, W., Wiedensohler, A., and Pratt, K. A.: Effect of 1070 Prudhoe Bay emissions on atmospheric aerosol growth events observed in Utqiagivik (Barrow), Alaska, 152, 146-155, https://doi.org/10.1016/j.atmosenv.2016.12.019, 2017.

Kulkarni, A. and von Storch, H.: Monte Carlo experiments on the effect of serial correlation on the Mann-Kendall test of trend, Meteorol. Z., 4, 82-85, 1995.

Leaitch, W. R., Russell, L. M., Liu, J., Kolonjari, F., Toom, D., Huang, L., Sharma, S., Chivulescu, A., Veber, D., and Zhang,

1075 W.: Organic functional groups in the submicron aerosol at $82.5^{\circ} \mathrm{N}, 62.5^{\circ} \mathrm{W}$ from 2012 to 2014, 18, 3269-3287, https://doi.org/10.5194/acp-18-3269-2018, 2018.

Mahmood, R., von Salzen, K., Flanner, M., Sand, M., Langner, J., Wang, H., and Huang, L.: Seasonality of global and Arctic black carbon processes in the Arctic Monitoring and Assessment Programme models, Journal of Geophysical Research: Atmospheres, 121, 7100-7116, https://doi.org/10.1002/2016JD024849, 2016.

1080 Mahmood, R., von Salzen, K., Norman, A. L., Galí, M., and Levasseur, M.: Sensitivity of Arctic sulfate aerosol and clouds to changes in future surface seawater dimethylsulfide concentrations, 19, 6419-6435, https://doi.org/10.5194/acp-19-6419-2019, 2019 .

van Marle, M. J. E., Kloster, S., Magi, B. I., Marlon, J. R., Daniau, A. L., Field, R. D., Arneth, A., Forrest, M., Hantson, S., Kehrwald, N. M., Knorr, W., Lasslop, G., Li, F., Mangeon, S., Yue, C., Kaiser, J. W., and van der Werf, G. R.: Historic global 1085 biomass burning emissions for CMIP6 (BB4CMIP) based on merging satellite observations with proxies and fire models (1750-2015), 10, 3329-3357, https://doi.org/10.5194/gmd-10-3329-2017, 2017.

Maslanik, J. A. and Stroeve, J.: Near-Real-Time DMSP SSMIS Daily Polar Gridded Sea Ice Concentrations, Version 1, https://doi.org/10.5067/U8C09DWVX9LM, 1999.

Matsui, H., Mahowald, N. M., Moteki, N., Hamilton, D. S., Ohata, S., Yoshida, A., Koike, M., Scanza, R. A., and Flanner, M. 1090 G.: Anthropogenic combustion iron as a complex climate forcer, Nature Communications, 9, 1593, https://doi.org/10.1038/s41467-018-03997-0, 2018. 
McCarty, J. L., Aalto, J., Paunu, V.-V., Arnold, S. R., Eckhardt, S., Klimont, Z., Fain, J. J., Evangeliou, N., Venäläinen, A., Tchebakova, N. M., Parfenova, E. I., Kupiainen, K., Soja, A. J., Huang, L., and Wilson, S.: Reviews \& Syntheses: Arctic Fire Regimes and Emissions in the 21st Century, Biogeosciences Discuss., 2021, 1-59, https://doi.org/10.5194/bg-2021-83, 2021.

Meier, W. N., Hovelsrud, G. K., van Oort, B. E. H., Key, J. R., Kovacs, K. M., Michel, C., Haas, C., Granskog, M. A., Gerland, S., Perovich, D. K., Makshtas, A., and Reist, J. D.: Arctic sea ice in transformation: A review of recent observed changes and impacts on biology and human activity, 52, 185-217, https://doi.org/10.1002/2013RG000431, 2014.

Moffett, C. E., Barrett, T. E., Liu, J., Gunsch, M. J., Upchurch, L. M., Quinn, P. K., Pratt, K. A., and Sheesley, R. J.: LongTerm Trends for Marine Sulfur Aerosol in the Alaskan Arctic and Relationships With Temperature, Journal of Geophysical Research: Atmospheres, 125, e2020JD033225, https://doi.org/10.1029/2020JD033225, 2020.

Morin, S., Savarino, J., Frey, M. M., Yan, N., Bekki, S., Bottenheim, J. W., and Martins, J. M. F.: Tracing the Origin and Fate of $\mathrm{NO}_{\mathrm{x}}$ in the Arctic Atmosphere Using Stable Isotopes in Nitrate, Science, 322, 730, https://doi.org/10.1126/science.1161910, 2008 .

Arctic Sea Ice Minimum: https://climate.nasa.gov/vital-signs/arctic-sea-ice/, last access: 31 December 2020.

1105 Nguyen, Q. T., Skov, H., Sørensen, L. L., Jensen, B. J., Grube, A. G., Massling, A., Glasius, M., and Nøjgaard, J. K.: Source apportionment of particles at Station Nord, North East Greenland during 2008-2010 using COPREM and PMF analysis, 13, 35-49, https://doi.org/10.5194/acp-13-35-2013, 2013.

Nguyen, Q. T., Glasius, M., Sørensen, L. L., Jensen, B., Skov, H., Birmili, W., Wiedensohler, A., Kristensson, A., Nøjgaard, J. K., and Massling, A.: Seasonal variation of atmospheric particle number concentrations, new particle formation and 1110 atmospheric oxidation capacity at the high Arctic site Villum Research Station, Station Nord, 16, 11319-11336, https://doi.org/10.5194/acp-16-11319-2016, 2016.

Nielsen, I. E., Skov, H., Massling, A., Eriksson, A. C., Dall’Osto, M., Junninen, H., Sarnela, N., Lange, R., Collier, S., Zhang, Q., Cappa, C. D., and Nøjgaard, J. K.: Biogenic and anthropogenic sources of aerosols at the High Arctic site Villum Research Station, 19, 10239-10256, https://doi.org/10.5194/acp-19-10239-2019, 2019.

1115 Park, K.-T., Yoon, Y. J., Lee, K., Tunved, P., Krejci, R., Ström, J., Jang, E., Kang, H. J., Jang, S., Park, J., Lee, B. Y., Traversi, R., Becagli, S., and Hermansen, O.: Dimethyl Sulfide-Induced Increase in Cloud Condensation Nuclei in the Arctic Atmosphere, Global Biogeochemical Cycles, 35, e2021GB006969, https://doi.org/10.1029/2021GB006969, 2021.

Petäjä, T., Duplissy, E.-M., Tabakova, K., Schmale, J., Altstädter, B., Ancellet, G., Arshinov, M., Balin, Y., Baltensperger, U., Bange, J., Beamish, A., Belan, B., Berchet, A., Bossi, R., Cairns, W. R. L., Ebinghaus, R., El Haddad, I., Ferreira-Araujo, B., 1120 Franck, A., Huang, L., Hyvärinen, A., Humbert, A., Kalogridis, A.-C., Konstantinov, P., Lampert, A., MacLeod, M., Magand, O., Mahura, A., Marelle, L., Masloboev, V., Moisseev, D., Moschos, V., Neckel, N., Onishi, T., Osterwalder, S., Ovaska, A., Paasonen, P., Panchenko, M., Pankratov, F., Pernov, J. B., Platis, A., Popovicheva, O., Raut, J.-C., Riandet, A., Sachs, T., Salvatori, R., Salzano, R., Schröder, L., Schön, M., Shevchenko, V., Skov, H., Sonke, J. E., Spolaor, A., Stathopoulos, V. K., Strahlendorff, M., Thomas, J. L., Vitale, V., Vratolis, S., Barbante, C., Chabrillat, S., Dommergue, A., Eleftheriadis, K.,

1125 Heilimo, J., Law, K. S., Massling, A., Noe, S. M., Paris, J.-D., Prévôt, A. S. H., Riipinen, I., Wehner, B., Xie, Z., and Lappalainen, H. K.: Overview: Integrative and Comprehensive Understanding on Polar Environments (iCUPE) - concept and initial results, Atmos. Chem. Phys., 20, 8551-8592, https://doi.org/10.5194/acp-20-8551-2020, 2020.

Pilson, M. E.: An Introduction to the Chemistry of the Sea, cambridge university press, 2012.

Platt, S. M., Hov, Ø., Berg, T., Breivik, K., Eckhardt, S., Eleftheriadis, K., Evangeliou, N., Fiebig, M., Fisher, R., Hansen, G., 
Krognes, T., Larssen, S., Lowry, D., Lund Myhre, C., Lunder, C., Nisbet, E., Nizetto, P. B., Park, K.-T., Pedersen, C. A., Aspmo Pfaffhuber, K., Röckmann, T., Schmidbauer, N., Solberg, S., Stohl, A., Ström, J., Svendby, T., Tunved, P., Tørnkvist, K., van der Veen, C., Vratolis, S., Yoon, Y. J., Yttri, K. E., Zieger, P., Aas, W., and Tørseth, K.: Atmospheric composition in the European Arctic and 30 years of the Zeppelin Observatory, Ny-Ålesund, Atmos. Chem. Phys. Discuss., 2021, 1-80, https://doi.org/10.5194/acp-2021-505, 2021.

Quinn, P. K., Miller, T. L., Bates, T. S., Ogren, J. A., Andrews, E., and Shaw, G. E.: A 3-year record of simultaneously measured aerosol chemical and optical properties at Barrow, Alaska, J. Geophys. Res.-Atmos., 107, 15, https://doi.org/10.1029/2001jd001248, 2002.

Quinn, P. K., Shaw, G., Andrews, E., Dutton, E. G., Ruoho-Airola, T., and Gong, S. L.: Arctic haze: current trends and knowledge gaps, Tellus Ser. B-Chem. Phys. Meteorol., 59, 99-114, https://doi.org/10.1111/j.1600-0889.2006.00238.x, 2007.

Quinn, P. K., Bates, T. S., Schulz, K., and Shaw, G. E.: Decadal trends in aerosol chemical composition at Barrow, Alaska: 1976-2008, Atmos. Chem. Phys., 9, 8883-8888, 2009.

Radke, L. F., Hobbs, P. V., and Pinnons, J. E.: Observations of Cloud Condensation Nuclei, Sodium-Containing Particles, Ice Nuclei and the Light-Scattering Coefficient Near Barrow, Alaska, Journal of Applied Meteorology and Climatology, 15, 982995, https://doi.org/10.1175/1520-0450(1976)015<0982:OOCCNS>2.0.CO;2, 1976.

Rigét, F., Bignert, A., Braune, B., Dam, M., Dietz, R., Evans, M., Green, N., Gunnlaugsdóttir, H., Hoydal, K. S., Kucklick, J., Letcher, R., Muir, D., Schuur, S., Sonne, C., Stern, G., Tomy, G., Vorkamp, K., and Wilson, S.: Temporal trends of persistent organic pollutants in Arctic marine and freshwater biota, Science of The Total Environment, 649, 99-110, https://doi.org/10.1016/j.scitotenv.2018.08.268, 2019.

1150 Rodríguez, B. T., Huang, L., Santos, G. M., Zhang, W., Vetro, V., Xu, X., Kim, S., and Czimczik, C. I.: Seasonal Cycle of Isotope-Based Source Apportionment of Elemental Carbon in Airborne Particulate Matter and Snow at Alert, Canada, Journal of Geophysical Research: Atmospheres, 125, e2020JD033125, https://doi.org/10.1029/2020JD033125, 2020.

Rogers, B. M., Balch, J. K., Goetz, S. J., Lehmann, C. E. R., and Turetsky, M.: Focus on changing fire regimes: interactions with climate, ecosystems, and society, 15, 030201, https://doi.org/10.1088/1748-9326/ab6d3a, 2020.

1155 Sand, M., Berntsen, T. K., von Salzen, K., Flanner, M. G., Langner, J., and Victor, D. G.: Response of Arctic temperature to changes in emissions of short-lived climate forcers, 6, 286, https://doi.org/10.1038/nclimate2880, 2015.

Schmale, J. and Baccarini, A.: Progress in Unravelling Atmospheric New Particle Formation and Growth across the Arctic, Geophysical Research Letters, n/a, e2021GL094198, https://doi.org/10.1029/2021GL094198, 2021.

Schmale, J., Schneider, J., Ancellet, G., Quennehen, B., Stohl, A., Sodemann, H., Burkhart, J. F., Hamburger, T., Arnold, S. 1160 R., Schwarzenboeck, A., Borrmann, S., and Law, K. S.: Source identification and airborne chemical characterisation of aerosol pollution from long-range transport over Greenland during POLARCAT summer campaign 2008, 11, 10097-10123, https://doi.org/10.5194/acp-11-10097-2011, 2011.

Schmale, J., Arnold, S. R., Law, K. S., Thorp, T., Anenberg, S., Simpson, W. R., Mao, J., and Pratt, K. A.: Local Arctic Air Pollution: A Neglected but Serious Problem, 6, 1385-1412, 2018.

1165 Schmeisser, L., Backman, J., Ogren, J. A., Andrews, E., Asmi, E., Starkweather, S., Uttal, T., Fiebig, M., Sharma, S., Eleftheriadis, K., Vratolis, S., Bergin, M., Tunved, P., and Jefferson, A.: Seasonality of aerosol optical properties in the Arctic, 18, 11599-11622, https://doi.org/10.5194/acp-18-11599-2018, 2018. 
Schnell, R. C.: Arctic haze and the Arctic Gas and Aerosol Sampling Program (AGASP), Geophys. Res. Lett., 11, 361-364, 1984.

1170 Seguin, A. M., Norman, A.-L., and Barrie, L.: Evidence of sea ice source in aerosol sulfate loading and size distribution in the Canadian High Arctic from isotopic analysis, 119, 1087-1096, https://doi.org/10.1002/2013JD020461, 2014.

Serreze, M. C. and Barry, R. G.: Processes and impacts of Arctic amplification: A research synthesis, 77, 85-96, https://doi.org/10.1016/j.gloplacha.2011.03.004, 2011.

Shah, V., Jaeglé, L., Thornton, J. A., Lopez-Hilfiker, F. D., Lee, B. H., Schroder, J. C., Campuzano-Jost, P., Jimenez, J. L., 1175 Guo, H., Sullivan, A. P., Weber, R. J., Green, J. R., Fiddler, M. N., Bililign, S., Campos, T. L., Stell, M., Weinheimer, A. J., Montzka, D. D., and Brown, S. S.: Chemical feedbacks weaken the wintertime response of particulate sulfate and nitrate to emissions reductions over the eastern United States, Proc Natl Acad Sci USA, 115, 8110, https://doi.org/10.1073/pnas.1803295115, 2018.

Sharma, S., Andrews, E., Barrie, L. A., Ogren, J. A., and Lavoué, D.: Variations and sources of the equivalent black carbon in the high Arctic revealed by long-term observations at Alert and Barrow: 1989-2003, 111, D14208, https://doi.org/10.1029/2005JD006581, 2006.

Sharma, S., Chan, E., Ishizawa, M., Toom-Sauntry, D., Gong, S. L., Li, S. M., Tarasick, D. W., Leaitch, W. R., Norman, A., Quinn, P. K., Bates, T. S., Levasseur, M., Barrie, L. A., and Maenhaut, W.: Influence of transport and ocean ice extent on biogenic aerosol sulfur in the Arctic atmosphere, Journal of Geophysical Research: Atmospheres, 117, 1185 https://doi.org/10.1029/2011JD017074, 2012.

Sharma, S., Ishizawa, M., Chan, D., Lavoué, D., Andrews, E., Eleftheriadis, K., and Maksyutov, S.: 16-year simulation of Arctic black carbon: Transport, source contribution, and sensitivity analysis on deposition, 118, 943-964, https://doi.org/10.1029/2012JD017774, 2013.

Sharma, S., Leaitch, W. R., Huang, L., Veber, D., Kolonjari, F., Zhang, W., Hanna, S. J., Bertram, A. K., and Ogren, J. A.: An 1190 evaluation of three methods for measuring black carbon in Alert, Canada, Atmos. Chem. Phys., 17, 15225-15243, https://doi.org/10.5194/acp-17-15225-2017, 2017.

Sharma, S., Barrie, L. A., Magnusson, E., Brattström, G., Leaitch, W. R., Steffen, A., and Landsberger, S.: A Factor and Trends Analysis of Multidecadal Lower Tropospheric Observations of Arctic Aerosol Composition, Black Carbon, Ozone, and Mercury at Alert, Canada, Journal of Geophysical Research: Atmospheres, 124, 14133-14161, 1195 https://doi.org/10.1029/2019JD030844, 2019.

Shaw, G. E.: The arctic haze phenomenon, Bull. Amer. Meteorol. Soc., 76, 2403-2413, 1995.

Shindell, D. T., Chin, M., Dentener, F., Doherty, R. M., Faluvegi, G., Fiore, A. M., Hess, P., Koch, D. M., MacKenzie, I. A., Sanderson, M. G., Schultz, M. G., Schulz, M., Stevenson, D. S., Teich, H., Textor, C., Wild, O., Bergmann, D. J., Bey, I., Bian, H., Cuvelier, C., Duncan, B. N., Folberth, G., Horowitz, L. W., Jonson, J., Kaminski, J. W., Marmer, E., Park, R., Pringle, 1200 K. J., Schroeder, S., Szopa, S., Takemura, T., Zeng, G., Keating, T. J., and Zuber, A.: A multi-model assessment of pollution transport to the Arctic, Atmos. Chem. Phys., 8, 5353-5372, 2008.

Skov, H., Hjorth, J., Nordstrøm, C., Jensen, B., Christoffersen, C., Bech Poulsen, M., Baldtzer Liisberg, J., Beddows, D., Dall'Osto, M., and Christensen, J. H.: Variability in gaseous elemental mercury at Villum Research Station, Station Nord, in North Greenland from 1999 to 2017, Atmos. Chem. Phys., 20, 13253-13265, https://doi.org/10.5194/acp-20-13253-2020, 2020 . 
Song, C., Dall'Osto, M., Lupi, A., Mazzola, M., Traversi, R., Becagli, S., Gilardoni, S., Vratolis, S., Yttri, K. E., Beddows, D. C. S., Schmale, J., Brean, J., Kramawijaya, A. G., Harrison, R. M., and Shi, Z.: Differentiation of coarse-mode anthropogenic, marine and dust particles in the high Arctic Islands of Svalbard, Atmos. Chem. Phys. Discuss., 2021, 1-33, https://doi.org/10.5194/acp-2021-94, 2021.

1210 Stohl, A.: Characteristics of atmospheric transport into the Arctic troposphere, J. Geophys. Res.-Atmos., 111, 17, https://doi.org/10.1029/2005jd006888, 2006.

Stohl, A., Andrews, E., Burkhart, J. F., Forster, C., Herber, A., Hoch, S. W., Kowal, D., Lunder, C., Mefford, T., Ogren, J. A., Sharma, S., Spichtinger, N., Stebel, K., Stone, R., Strom, J., Torseth, K., Wehrli, C., and Yttri, K. E.: Pan-Arctic enhancements of light absorbing aerosol concentrations due to North American boreal forest fires during summer 2004, J. Geophys. Res.Atmos., 111, 20, https://doi.org/10.1029/2006jd007216, 2006.

Stohl, A., Berg, T., Burkhart, J. F., Fjaeraa, A. M., Forster, C., Herber, A., Hov, O., Lunder, C., McMillan, W. W., Oltmans, S., Shiobara, M., Simpson, D., Solberg, S., Stebel, K., Strom, J., Torseth, K., Treffeisen, R., Virkkunen, K., and Yttri, K. E.: Arctic smoke - record high air pollution levels in the European Arctic due to agricultural fires in Eastern Europe in spring 2006, Atmos. Chem. Phys., 7, 511-534, 2007.

1220 Stohl, A., Klimont, Z., Eckhardt, S., Kupiainen, K., Shevchenko, V. P., Kopeikin, V. M., and Novigatsky, A. N.: Black carbon in the Arctic: the underestimated role of gas flaring and residential combustion emissions, 13, 8833-8855, https://doi.org/10.5194/acp-13-8833-2013, 2013.

Struthers, H., Ekman, A. M. L., Glantz, P., Iversen, T., Kirkevåg, A., Mårtensson, E. M., Seland, Ø., and Nilsson, E. D.: The effect of sea ice loss on sea salt aerosol concentrations and the radiative balance in the Arctic, 11, 3459-3477, https://doi.org/10.5194/acp-11-3459-2011, 2011.

Sturges, W. T. and Barrie, L. A.: Stable lead isotope ratios in arctic aerosols: evidence for the origin of arctic air pollution, Atmospheric Environment (1967), 23, 2513-2519, https://doi.org/10.1016/0004-6981(89)90263-1, 1989.

Thomas, J. L., Polashenski, C. M., Soja, A. J., Marelle, L., Casey, K. A., Choi, H. D., Raut, J. C., Wiedinmyer, C., Emmons, L. K., Fast, J. D., Pelon, J., Law, K. S., Flanner, M. G., and Dibb, J. E.: Quantifying black carbon deposition over the Greenland ice sheet from forest fires in Canada, 44, 7965-7974, https://doi.org/10.1002/2017GL073701, 2017.

Traversi, R., Becagli, S., Caiazzo, L., Mazzola, M., Lupi, A., Fiebig, M., Hermansen, O., and Krejci, R.: Arctic haze in a climate changing world: the 2010-2020 trend (HAZECLIC), https://doi.org/10.5281/zenodo.4293826, 2021.

Tunved, P. and Ström, J.: On the seasonal variation in observed size distributions in northern Europe and their changes with decreasing anthropogenic emissions in Europe: climatology and trend analysis based on 17 years of data from Aspvreten, Sweden, Atmos. Chem. Phys., 19, 14849-14873, https://doi.org/10.5194/acp-19-14849-2019, 2019.

Tunved, P., Hansson, H. C., Kulmala, M., Aalto, P., Viisanen, Y., Karlsson, H., Kristensson, A., Swietlicki, E., Dal Maso, M., Ström, J., and Komppula, M.: One year boundary layer aerosol size distribution data from five nordic background stations, 3, 2183-2205, https://doi.org/10.5194/acp-3-2183-2003, 2003.

Tunved, P., Hansson, H.-C., Kerminen, V.-M., Ström, J., Maso, M. D., Lihavainen, H., Viisanen, Y., Aalto, P. P., Komppula, 1240 M., and Kulmala, M.: High Natural Aerosol Loading over Boreal Forests, Science, 312, 261, https://doi.org/10.1126/science.1123052, 2006.

Udisti, R., Bazzano, A., Becagli, S., Bolzacchini, E., Caiazzo, L., Cappelletti, D., Ferrero, L., Frosini, D., Giardi, F., Grotti, M., Lupi, A., Malandrino, M., Mazzola, M., Moroni, B., Severi, M., Traversi, R., Viola, A., and Vitale, V.: Sulfate source 
https://doi.org/10.5194/acp-2021-756

Preprint. Discussion started: 8 September 2021

(c) Author(s) 2021. CC BY 4.0 License.

(c) (1)

apportionment in the Ny-Ålesund (Svalbard Islands) Arctic aerosol, Rendiconti Lincei, 27, 85-94, https://doi.org/10.1007/s12210-016-0517-7, 2016.

Willis, M. D., Köllner, F., Burkart, J., Bozem, H., Thomas, J. L., Schneider, J., Aliabadi, A. A., Hoor, P. M., Schulz, H., Herber, A. B., Leaitch, W. R., and Abbatt, J. P. D.: Evidence for marine biogenic influence on summertime Arctic aerosol, 44, 6460-6470, https://doi.org/10.1002/2017GL073359, 2017.

Winiger, P., Barrett, T. E., Sheesley, R. J., Huang, L., Sharma, S., Barrie, L. A., Yttri, K. E., Evangeliou, N., Eckhardt, S., 1250 Stohl, A., Klimont, Z., Heyes, C., Semiletov, I. P., Dudarev, O. V., Charkin, A., Shakhova, N., Holmstrand, H., Andersson, A., and Gustafsson, Ö.: Source apportionment of circum-Arctic atmospheric black carbon from isotopes and modeling, Sci Adv, 5, eaau8052, https://doi.org/10.1126/sciadv.aau8052, 2019. 